\title{
Translational Regulations in Response to Endoplasmic Reticulum Stress in Cancers
}

\author{
Manon Jaud ${ }^{1,2, \dagger}$, Céline Philippe ${ }^{3, \dagger}$, Doriana Di Bella ${ }^{3}$, Weiwei Tang ${ }^{3}$, Stéphane Pyronnet ${ }^{1,2}$, \\ Henrik Laurell ${ }^{2,4} \mathbb{D}$, Laurent Mazzolini ${ }^{1,5}{ }^{(0)}$, Kevin Rouault-Pierre ${ }^{3}$ and Christian Touriol ${ }^{1,2, *(\mathbb{D}}$ \\ 1 Inserm UMR1037, CRCT (Cancer Research Center of Toulouse), F-31037 Toulouse, France; \\ manon.jaud@inserm.fr (M.J.); stephane.pyronnet@inserm.fr (S.P.); laurent.mazzolini@inserm.fr (L.M.) \\ 2 Université Toulouse III Paul-Sabatier, F-31000 Toulouse, France; henrik.laurell@inserm.fr \\ 3 Barts Cancer Institute, Queen Mary University of London, London E1 4NS, UK; c.philippe@qmul.ac.uk (C.P.); \\ doriana.dibella@qmul.ac.uk (D.D.B.); weiwei.tang@qmul.ac.uk (W.T.); k.rouault-pierre@qmul.ac.uk (K.R.-P.) \\ 4 Inserm UMR1048, I2MC (Institut des Maladies Métaboliques et Cardiovasculaires), BP 84225, CEDEX 04, \\ 31432 Toulouse, France \\ 5 CNRS ERL5294, CRCT, F-31037 Toulouse, France \\ * Correspondence: christian.touriol@inserm.fr \\ + These two authors contributed equally to this work.
}

Received: 20 December 2019; Accepted: 24 February 2020; Published: 26 February 2020

check for updates

\begin{abstract}
During carcinogenesis, almost all the biological processes are modified in one way or another. Among these biological processes affected, anomalies in protein synthesis are common in cancers. Indeed, cancer cells are subjected to a wide range of stresses, which include physical injuries, hypoxia, nutrient starvation, as well as mitotic, oxidative or genotoxic stresses. All of these stresses will cause the accumulation of unfolded proteins in the Endoplasmic Reticulum (ER), which is a major organelle that is involved in protein synthesis, preservation of cellular homeostasis, and adaptation to unfavourable environment. The accumulation of unfolded proteins in the endoplasmic reticulum causes stress triggering an unfolded protein response in order to promote cell survival or to induce apoptosis in case of chronic stress. Transcription and also translational reprogramming are tightly controlled during the unfolded protein response to ensure selective gene expression. The majority of stresses, including ER stress, induce firstly a decrease in global protein synthesis accompanied by the induction of alternative mechanisms for initiating the translation of mRNA, later followed by a translational recovery. After a presentation of ER stress and the UPR response, we will briefly present the different modes of translation initiation, then address the specific translational regulatory mechanisms acting during reticulum stress in cancers and highlight the importance of translational control by ER stress in tumours.
\end{abstract}

Keywords: translation initiation; ER stress; unfolded protein response (UPR); IRES; uORF

\section{Introduction}

Over the years, eukaryotic cells have evolved different mechanisms to deal with stressful environments. Under stress conditions, eukaryotic cells activate adaptive pathways to restore cellular homeostasis and to save energy. Given that cells consume a large amount of their available energy for the process of translation and for protein folding, it is not surprising that most stresses cause an inhibition in global protein synthesis. Indeed, under stress conditions, the maintenance of routine translation machinery would be deleterious. Hence the synthesis of "housekeeping" proteins is paused in stressed cells, whereas the translation of a pool of proteins necessary for the adaptive stress response is maintained, via alternative mechanisms of translational initiation. This level of regulation 
is particularly important in stress conditions, as it enables a rapid change in the protein synthesis level both quantitatively and qualitatively to obtain a response that is relevant to the type of stress being induced.

This is particularly true in cells with high growth rates and elevated metabolic requirements such as cancer cells, which are exposed to environmental stresses because of inadequate vascularisation causing hypoxia, acidosis and nutrient starvation. All of these stresses have been reported to cause the accumulation of unfolded or misfolded proteins in the lumen of the endoplasmic reticulum (ER) and induce ER stress because the folding capacity of the ER is limited. ER stress triggers activation of the unfolded protein response (UPR), an adaptive reaction mediated by three molecular sensors present on the membrane of endoplasmic reticulum: Activated Transcription Factor 6 (ATF6), Inositol-Requiring Enzyme 1 (IRE1) and PKR-like ER kinase (PERK). UPR activation in cells alters both transcriptional and translational programs to coordinate adaptive and/or apoptotic responses.

Indeed, UPR aims to restore cellular homeostasis and to promote cell survival by inhibiting protein synthesis, improving protein folding ability, increasing the degradation of unfolded proteins. However, when damages are irreversible after intense and prolonged activation, UPR induces cell death. At the moment, the molecular determinants of the transition from survival to death are still unknown.

Even if PERK kinase activation, which leads to phosphorylation of eukaryotic translation initiation factor- $2 \alpha(\mathrm{eIF} 2 \alpha)$, is required for the global translation reprogramming during ER stress, involvement of IRE1 in translational regulation has also been established.

It should be noted that the regulation of translation is extremely complex, with many interconnected mechanisms. Our aim here is not to go into the details of the various translation initiation modes, but to give the reader an overview of the translation rewiring upon stress. After a brief presentation of Endoplasmic Reticulum stress and UPR response, a particularly complex mechanism but also well documented in the literature, we will focus on the translational regulatory mechanisms acting during this stress in cancers and highlight the importance of translational control in stress conditions.

\section{Endoplasmic Reticulum Stress Signalling in Cancer}

The endoplasmic reticulum (ER), which accounts for more than $50 \%$ of the cell's membranes in certain cells, is the site of synthesis and modification of secreted and membrane-related proteins (up to $50 \%$ of all proteins in certain cell types) [1,2]. It represents, therefore, an important hub where proteins undergo very strict quality control ensuring that only properly folded proteins progress down the secretory pathway. Thus, all situations leading to an alteration of the ER function, including the accumulation of excess unfolded proteins in the lumen of endoplasmic reticulum, lead to ER stress. Given the harmful impact of unfolded proteins, it is crucial that cells adapt to an imbalance between the ER's folding capacity and unfolded proteins accumulation. The physiological response caused by the accumulation of misfolded or unfolded proteins is commonly called unfolded protein response (UPR) $[2,3]$.

During cancer development and progression, cells are under a wide range of stresses, which include changes in oxygen levels (hypoxia), acidosis, nutrient starvation, disrupted calcium homeostasis, genotoxic or oxidative stresses. All of these stresses induce an accumulation of unfolded proteins within the reticulum, thus activating the UPR. In addition, cells with high proliferation rate, such as cancer cells, have to sustain a high rate of protein synthesis and massive protein flow through ER, leading to accumulation of misfolded protein in the ER, perturbation of ER homeostasis and finally to ER stress [4]. It has also been shown that genetic alterations found in cancers (translocations, mutations, aneuploidy, etc.) could be linked to the establishment of chronic ER stress [5-7]. ER stress and UPR are, therefore, the focal point of a large number of endogenous or exogenous cellular stresses.

\subsection{The Unfolded Protein Response}

In mammals, UPR is triggered by activation of three ER transmembrane sensors: PERK, ATF6, and IRE1 $[3,8,9]$. The luminal part of these proteins integrates the information coming from the ER 
lumen whereas their cytoplasmic part interacts with the effectors and mediates the signalling cascades (Figure 1). In absence of stress, the ER resident protein chaperone BiP interacts with the luminal domain of the three effectors and keep them in an inactive state. Upon accumulation of unfolded proteins in the ER lumen, BiP will act as a protein chaperone. Indeed, BiP has a relatively low but very broad affinity for hydrophobic regions of proteins, enabling it to recognise and bind a wide range of misfolded proteins exposing hydrophobic segments. As a consequence of its binding to the misfolded proteins, BiP is released from ATF6, IRE1, and PERK, leading to their activation $[3,8,9]$.

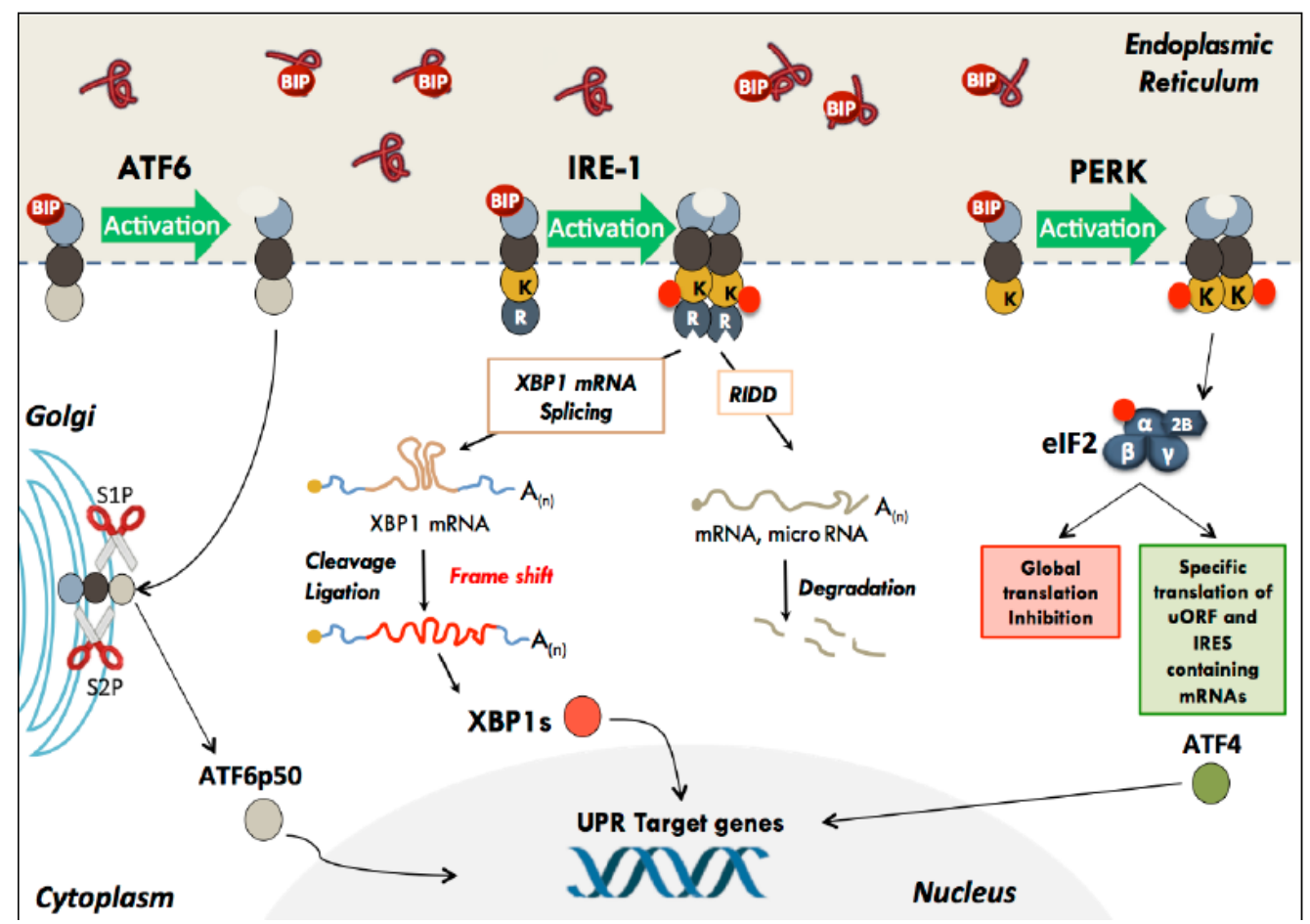

Figure 1. The different UPR effectors and their modes of action. In the basal state, the three UPR effector transmembrane proteins (PERK, ATF6, and IRE-1) are maintained inactive through their interaction with the protein chaperone BiP. The accumulation of poorly folded polypeptides in the ER lumen results in dissociation of $\mathrm{BiP}$ and activation of UPR. -I- PERK dimerises and phosphorylates the eIF2 $\alpha$ subunit, leading to a global translation initiation inhibition. Specific mRNA subsets, containing cis-acting elements in their $5^{\prime} \mathrm{UTR}$, such as uORF and IRES, escape translational inhibition triggered by eIF2 phosphorylation. -II- IRE-1 initiates an unconventional splicing of XBP-1 mRNA, as well as the degradation of some RNAs (this mechanism has been called RIDD for Regulated Ire1-Dependent Decay) -III- ATF6 traffics to the Golgi where proteolysis liberates its transcription factor amino-terminal domain, which is nuclearised and activates the expression of target genes.

Each of the three activated pathways will contribute, sometimes in a redundant way, to the stress response. Indeed, activation of these 3 sensors, namely IRE1, ATF6, and PERK, induce protective feedback mechanism essential to restore ER homeostasis through translation inhibition, to reduce protein synthesis, enhancing degradation of misfolded proteins and transcriptional regulation of specific stress target genes.

More generally, it seems that many chaperone proteins, residing in the endoplasmic reticulum, may be involved in the regulation of the activation/inactivation of UPR sensors. First of all, the involvement of different proteins of the PDI family (Protein Disulfite Isomerase) has been highlighted. PDIA5 has been described to interact with the ATF6 protein by modifying its conformation and consequently facilitating its export from ER [10]. Similarly, PDIA6 binds the disulfide bridges of the active IRE1 and PERK proteins and promotes their inactivation [11]. More recently, an original 
mechanism for activating IRE1 has been identified. The chaperone protein HSP47 directly binds the luminal domain of IRE1 and dislodges the BiP protein [12]. This mechanism promotes the activation of the IRE1 protein. Thus, HSP47 deficiency sensitises the cells to endoplasmic reticulum stress. Through screening of different IRE1 protein partners, this study revealed that other proteins such as mitochondrial ATPase Atp5h or phosphatase PP2a, are able to regulate IRE1 activity [12]. It has also been proposed that unfolded proteins may bind IRE1 thus promoting its oligomerisation and potentially modifying its activity [13].

The activation of the three UPR sensors, therefore, seems finely regulated and a better understanding of the mechanisms involved in these regulations could eventually allow each of these pathways to be specifically modulated.

However, after activation of these three pathways, UPR fosters cell survival in response to stress in the following three ways: (i) blockade of protein translation to re-establish homeostasis; (ii) positive regulation of molecular chaperones to promote protein folding (iii) up-regulation of signalling pathways responsible for targeting ER misfolded proteins to degradation after ubiquitination. In addition, to promoting cellular survival, UPR can however also induce apoptosis under chronic or unresolved ER stress $[14,15]$.

\subsection{ATF6}

ATF6 is a basic Leucine Zipper transcription factor (bZIP) with two isoforms, ATF6 $\alpha$ and $\beta$. ATF6 $\beta$ is a distant homologue of ATF $6 \alpha$, and both are ubiquitously expressed. These two isoforms differ in their transactivation domain. As a result, a modulation of transcriptional activity is observed between the two proteins and is lower in the case of ATF6 $\beta$ [16]. The individual Knock-Out (KO) of each of these genes does not cause embryonic lethality [17]. In contrast, the double KO ATF $6 \alpha / \beta^{-/-}$ triggers an embryonic lethality at E8.5, suggesting that some mutual compensations may be established between the two isoforms [17]. Unlike the other two sensors (PERK and IRE1), ATF6 is both a sensor and a direct effector of the UPR. Indeed, during stress, release of BiP unmasks a Golgi Localisation Signal (or GLS) in its C-terminal intra-luminal part [18]. ATF6 is then addressed to the Golgi and processed by two proteases (S1P and S2P) into an active ATF6p50 transcription factor [19]. Thus activated, ATF6p50 is nuclearised and participates in the transcription of stress response genes whose promoter contains UPRE (Unfolded Protein Response Element) or ERSE (ER Stress-Response Element) nucleotide motifs elements [19]. It activates specific transcriptional programs involved in (i) ER folding capacities enhancement by activating chaperone proteins [20,21], and (ii) increased protein turnover through the Endoplasmic Reticulum Associated Degradation system (ERAD) by upregulating genes such as EDEM (ER Degradation Enhancing alpha-Mannosidase like protein) or HERP (Homocysteine-responsive ER-resident ubiquitin-like domain member 1 Protein) [17]. ATF6 also activates expression of several transcription factors such as CHOP (C/EBP homologous protein) and XBP1(X-Box Binding Protein 1) [22,23].

ATF6 has been associated with cancer development, however its role in tumours has not been fully elucidated yet. In chronic myeloid leukemia, ATF6 drives cell survival upon imatinib treatment [10]. Some evidences also showed that ATF6 plays an important role on cell dormancy in rapamycin-treated tumours [24]. All together, these findings shed light on the potential role of ATF6 in chemoresistance.

\subsection{IRE-1}

IRE1 is the most conserved UPR sensor in eukaryotic cells, and is also the only one that has an embryonic lethal knockout phenotype at E12.5, resulting from a defective placental vascularisation [25]. The mammalian genome encodes two IRE1 isoforms, IRE1 $\alpha$ and IRE1 $\beta$. The first one is ubiquitously expressed while IRE1 $\beta$ expression is restricted to intestinal epithelial cells [26] and airway mucous cells [27].

IRE1 is a bifunctional protein, characterised by two cytoplasmic catalytic domains in its carboxy-terminal part: a serine/threonine kinase domain fused to an endoribonuclease domain 
(RNAse). During endoplasmic reticulum stress, protein dimerisation/oligomerisation triggers trans-autophosphorylation of the kinase domains, thereby inducing a conformational change leading to the allosteric activation of the RNase domain [14]. IRE1 activates several downstream intracellular signalling pathways through its RNAse activity and through its kinase activity. Indeed, it has been reported that the kinase domain is able to recruit the protein TRAF2 (TNF receptor-associated factor 2). The IRE1/TRAF2 complex then interacts with ASK1 (apoptosis signal-regulating kinase 1) to activate the JNK, c-Jun N-terminal kinase thus activating the pro-apoptotic ASK1/JNK (c-Jun N-terminal kinase pathway) $[28,29]$.

The IRE1 endoribonuclease activity was first described for its role in cytoplasmic splicing of XBP1 (X-Box Binding Protein 1) mRNA. Once activated, IRE1 initiates the non-conventional XBP1 splicing by cleaving the mRNA at two sites in a conserved stem-loop structure folded sequence located in the open reading frame [30]. The excised sequence, whose length differs depending on the species, is composed of 26 nucleotides in humans.

Then, the cleaved mRNA is processed by the tRNA ligase RTCB [31]. This unconventional splicing results in a frame-shift that allows the expression of an extended protein encompassing the transactivation domain of the transcription factor: XBP1s (s for spliced). The proteins XBP1s and $\mathrm{XBP} 1 \mathrm{u}(\mathrm{u}$ for unspliced), therefore, only differ by the presence or absence of the transactivation domain located in the C-terminal part, which also influences the stability of the proteins.

XBP1 splicing by IRE1 is a co-translational mechanism [32-34]. The nascent XBP1 protein possesses a highly hydrophobic domain (HR2), which enables the RNA/protein complex to be addressed to the endoplasmic reticulum membrane. More recently, it has been proposed that this relocalisation could happen indirectly through the recognition of the HR2 domain by the SRP (Signal Recognition Particle), which addresses the XBP1 mRNA to the IRE1/SEC61 complex [32]. A translational pause site would also facilitate this step [33].

Once activated, XBP1s induces the transcription of target genes for stress response by binding to UPRE or ERSE sequences in the promoter, but ChIP-seq studies have also shown that the role of XBP1s can extend to other cellular processes such as differentiation [35].

The endoribonuclease activity of IRE1 has been implicated in an additional process. For some other RNA targets, including both non-coding and coding RNA, the endonucleolytic cleavage by IRE1, sensitises these transcripts to the action of cytoplasmic exonucleases, triggering RNA decay. This mechanism, first described in Drosophila, is termed RIDD for Regulated IRE1-Dependent Decay [36]. Currently, only few direct targets have been characterised, however transcriptomic and bioinformatic studies seem to reveal a much broader spectrum of action [37,38]. Among the characterised RNA targets are 4 microRNAs (miR-17, 96, 125b, 34a) [39] and some mRNAs including PER1 [40], SPARC [41], BLOS1 [42], and DR5 [43]. Prediction of the RNA targets is relatively complex because no consensus sequence has been clearly defined even though an "XBP1-like" stem loop structure can be found at the cleavage site [44].

It remains to be determined how IRE1 selects between XBP1 splicing and RIDD. Given that both dimers and IRE1 oligomers have been detected during ER stress [45-47], it is likely that the RIDD mechanism can be influenced by IRE1's oligomerisation status. Indeed, in addition to its intra-luminal dimerisation domain, IRE1 also contains a cytoplasmic oligomerisation domain leading to the formation of clusters that can be visualised as foci at the ER level during UPR [47]. While some studies showed that a high oligomerisation is correlated with activation of the RIDD [48], other experiments revealed an opposite effect [47]. Therefore, the precise impact of IRE1 oligomerisation status on XBP1 splicing and RIDD awaits further clarification.

IRE1 mutations can be found in cancers however the biological significance remains to be determined [15]. For instance, in glioblastoma, IRE1 has been widely investigated and shown to contribute to cancer progression by different mechanisms such as promotion of angiogenesis, tumour invasion and also inflammation [49]. Whereas, another study reported a negative regulation of invasion by IRE1 in a glioblastoma model [50]. 
Interestingly the main downstream effector of IRE1, XBP1 has also been found mutated in cancer [51]. Despite recent efforts to investigate the RIDD branch, XBP1 remains the most described target of IRE1 and thus the most studied in cancer, so far. In triple-negative breast cancers, upon hypoxia, XBP1 cooperates with HIF1a to promote tumour growth and foster relapse by activating pathways such as angiogenesis and glucose metabolism [52]. However, the pro-tumoural or anti-tumoural role of XBP1 in cancer is discussed and is probably context-dependent. In Multiple Myeloma, for instance, a high expression of XBP1s correlates with a lower response to thalidomide-based treatment [53] while a high XBP1s expression correlated with a better response to Bortezomib-based chemotherapy [54]. Moreover, two inactivating mutations of XBP1 have been characterised in multiple myeloma patients and are responsible for resistance to bortezomib treatment $[55,56]$. Therefore, further investigations are required to understand the role of the canonical and non-canonical IRE1's pathways in cancers.

\subsection{PERK}

PERK is found in all metazoans and has the same domain organisation as IRE1; both proteins share a structurally- and functionally-related intra-luminal sensor domain [57] but a different cytoplasmic domain. The PERK monomer (encoded by the EIF2AK3 gene for eukaryotic translation initiation factor 2-alpha kinase 3) is located inside the ER membrane. The intra-luminal N-terminal part of PERK binds to $\mathrm{BiP}$, which prevents its dimerisation, while its cytoplasmic C-terminal region contains a serine/threonine protein kinase domain. During the UPR, BiP is released from PERK, thereby allowing dimerisation and trans-autophosphorylation at Thr-982, which endows PERK with its catalytic activity $[58,59]$. Activated PERK, in turn, phosphorylates the subunit of eukaryotic initiation factor eIF $2 \alpha$ at serine 51. The final consequence of PERK activation is the decrease in protein synthesis by rapid and potent inhibition of global translational initiation.

Other PERK substrates have been identified: (i) Nrf2 (Nuclear factor (erythroid-derived 2)-like 2) transcription factor, which is a master regulator of redox homeostasis and whose stability is increased after PERK-dependent phosphorylation of the threonine 80 leading to increased Nrf2 nuclear import [60]. (ii) FOXO3, one of the Forkhead transcription factor family members which regulates a set of genes that contribute to cellular homeostasis and whose activity is increased after its PERK-dependent phosphorylation of serines 261, 298, 301, 303 and 311 [61]. (iii) Multiple DAG (diacyglycerol) species, which are important second messengers [62].

A key point of the present review is the PERK-eIF2 $\alpha$ UPR signalling pathway, which is the most studied and, therefore, the best characterised. It's however important to note that three additional eIF2 $\alpha$ kinases have been discovered in mammalian cells which can be activated by different stresses: PKR, GCN2, and HRI. PKR is activated by long double-strand RNA and thus senses viral double-stranded RNA in infected cells [63-65]. GCN2 (general control nonderepressible 2) is activated by amino acid starvation through binding to uncharged tRNAs [66], or by UV irradiation [67,68]. Heme-regulated inhibitor (HRI) is known to get activated in various stresses, such as heme deficiency or heat shock in erythroid cells [69].

Much evidence showed an essential role of PERK in cancer. The PERK-ATF4 pathway induces autophagy in MYC-induced lymphoma and support the transformation process and tumour growth $[70,71]$. Furthermore, the PERK pathway has been reported to trigger a multidrug resistance phenotype in different tumour types through the PERK/Nrf2/MRP1 axis [72]. PERK is also closely linked to the anti-oxidative response. Whereby, by limiting oxidative DNA damages, PERK has been shown to enhance tumour growth [60]. The PERK-ATF4 axis has also been associated with metastasis through the transcription of matrix metalloproteinases [73]. Preclinical use of PERK inhibitors has shown great efficiency in pancreatic cancers [74]. However, the complexity of the downstream network activated by PERK suggests that the effect of PERK activation needs to be addressed in a context-dependent manner. 


\section{Translational Regulation: Dealing with Endoplasmic Reticulum Stress}

Many studies have supported the idea that the UPR requires translational reprogramming, in which protein synthesis is globally repressed and is accompanied by the preferential synthesis of a specific subset of mRNAs whose protein products are required for responding to ER stress $[45,75,76]$. Indeed, while IRE1-XBP1 and ATF6 are well known to elicit a transcriptional response, the PERK pathway mainly induces an overall translational shutdown response by phosphorylating eIF $2 \alpha$, but it also enables increased translation of many stress-related genes including the transcription factor ATF4, which mediates a secondary transcriptional response. Although global translation inhibition allows cellular resources to be preserved, an efficient synthesis of some factors is necessary to cope with the consequences of stress. Mammalian mRNAs whose expression is known to escape translational inhibition triggered by eIF $2 \alpha$ phosphorylation contain specific features in their $5^{\prime}$ untranslated region including uORF or IRES. After a brief reminder of the basics of mRNA translation initiation, we will develop some examples of RNA whose translation is upregulated during ER stress in more detail in the following paragraph. We will also discuss studies demonstrating the involvement of IRE1 RNase activity in translational regulations during reticulum stress.

\subsection{Canonical Cap-Dependent Translation Initiation}

Translation is a high demanding energy process, which needs to be rationalised upon stress conditions. The most well-known stress-relative pathways have been described to play critical roles in the regulation of the initiation step. In a nutshell, the general cap-dependent translation is turned off under stress conditions while the translation of some specific mRNAs is maintained or activated. Therefore, in order to understand the specific alternative routes of translation involved during stress, it is essential to understand the fine-tuning of the canonical cap-dependent translation initiation (Figure 2A).

Ribosomes were identified as the link between mRNA and proteins in the 1950s, while the m7G-cap discovery came later with a first description in viruses in 1975 [77]. During those years, many efforts were made to identify this structure in eukaryotic mRNA and eventually led to the characterisation of the cap structure in HeLa and mouse myeloma cells [77]. The cap consists of a methylated guanine (m7G), which is engaged in an unconventional $5^{\prime}$ to $5^{\prime}$ triphosphate linkage to the mRNA. This structure plays an essential role in the mRNA stability and the regulation of translation initiation [77].

In order to interact with the cap, start scanning and initiate translation, the $40 \mathrm{~S}$ small ribosome subunit (SSU) needs to be loaded. This priming is orchestrated by key actors of the translation, called eukaryotic initiation factors (eIFs): eIF3, eIF1/1A. In brief, eIF3 is binding the SSU in order to allow its recruitment at the cap. On the other hand, eIF1 and eIF1a are regulating the tRNA binding by stabilizing the preinitiation complex (PIC) in an open conformation. A third member of the eIFs family, eIF2 binds the SSU within a complex that also includes the methionine RNA transfer (Met-tRNAi), hence creating the ternary complex. The association of eIF2 and Met-tRNAi is allowed when eIF2 is loaded with a GTP. Therefore, the eIF2-GDP recycling into eIF2-GTP is a critical, rate-limiting, and highly regulated step, which is catalysed by the guanine exchange factor, eIF2B. At this stage, the SSU is comprised of eIF3, eIF1/1A and the ternary complex (eIF2-GTP-Met-tRNAi) thus forming the 43S pre-initiation complex [78-81].

The 43S PIC complex has the ability to bind the m7 GTP-cap through the heterotrimeric eIF4F complex composed of three non-identical subunits: the cap-binding protein eIF4E, the DEAD-box RNA helicase eIF4A, and the large "scaffold" protein eIF4G. This interaction recruits the PIC on the mRNA and the ATP-dependent scanning of the 5'UTR is initiated. When the first AUG enters the P-site of the SSU, the perfect codon/anti-codon matching triggers irreversible GTP hydrolysis in the ternary complex. Cooperative events are also required to fully complete the AUG recognition such as the release of eIF 1 and 2 . Then the binding of the $60 \mathrm{~S}$ subunit to the $40 \mathrm{~S}$ is catalysed by eIF5B-GTP and enables the first elongation step [78]. 


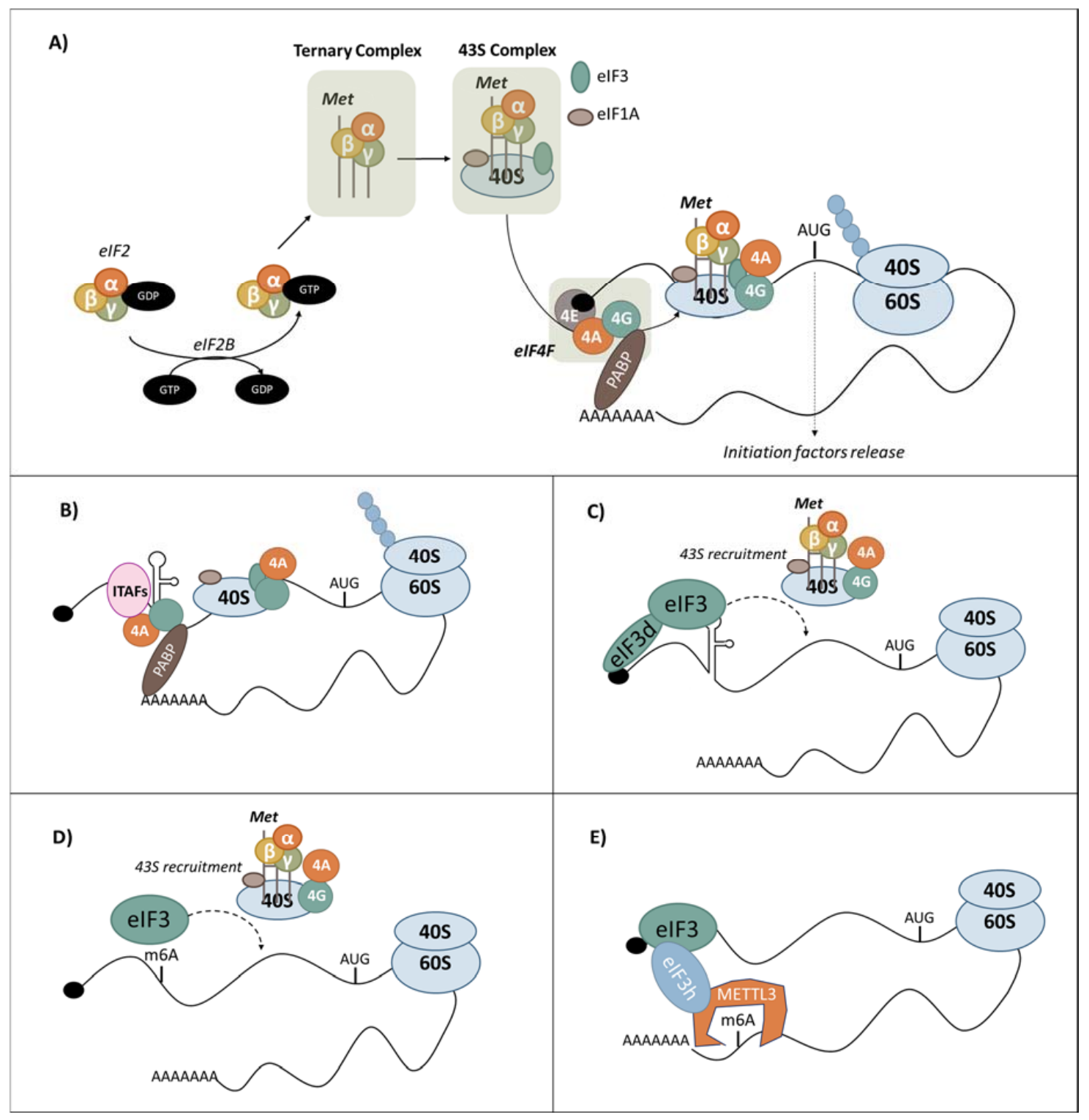

Figure 2. Currently known processes of translation initiation (A) Cap-dependent mechanism of translation. The eukaryotic initiation factor 2 (eIF2)-GDP is recycled in eIF2-GTP by the enzyme eIF2B. eIF2-GTP binds the methionine transfer RNA (Met-tRNAi) in order to form the ternary complex which integrates the $43 \mathrm{~S}$ complex comprising the $40 \mathrm{~S}$ ribosome subunit, eukaryotic initiation factors (eIF3, eIF1/1A) and the ternary complex. $43 \mathrm{~S}$ is recruited to the mRNA through the m7G cap by interacting with the eIF4F complex (eIF4E, eIF4A, eIF4G) and 43S scans the 5'UTR until the first starting codon. The codon/anti-codon interaction triggers the release of initiation factors and the recruitment of the 60S, and then elongation can start. (B) Internal ribosome entry sites (IRES)-mediated translation initiation. The IRES directly recruits ribosomes, thereby bypassing the requirement of the mRNA $5^{\prime}$ cap structure. (C) The binding of the cap by the eIF3d subunit in presence of the stem-loop in the $5^{\prime}$ UTR can bypass the canonical eIF4E translation and initiate an eIF3d-directed cap-dependent mRNA translation. (D) A single 5' UTR-located N(6)-methyladenosine m(6)A can promote cap-independent mRNA translation initiation, through direct interaction with eIF3 which is sufficient to recruit the $43 \mathrm{~S}$ complex and initiate translation even in the absence of the cap-binding factor eIF4E. (E) METTL3 enhances translation of mRNA containing $\mathrm{m}(6) \mathrm{A}$ in its $3^{\prime}$ UTR through interaction with eIF3h. 
Although the 5'UTR plays a central role in the translation initiation process, it is important to mention that the $3^{\prime}$ UTR is also involved in the regulation of translation initiation. Indeed, the poly(A)-binding protein (PABP) interacts with the cap through eIF4G and eIF4B, leading to the circularisation of the mRNA. A deregulation of this interaction can compromise translation [79]. Furthermore, circularisation of mRNA brings the $3^{\prime} \mathrm{UTR}$ binding regulators, such as micro-RNA or RNA binding proteins, next to the $5^{\prime} \mathrm{UTR}$, giving them the ability to modulate the translation initiation step [81]. A key example is the mechanism of action of the Bicoid protein, which regulates the translation of mRNA during the development of Drosophila. Bicoid suppresses translation of caudal mRNA at the anterior of the embryo by binding the 3'UTR and an eIF4E-related protein, which compete with eIF4E in the binding of eIF4G [82].

\subsection{Translational Control PERK-Mediated under ER Stress}

Due to its central role during the recruitment of the initiator tRNA, the alpha subunit of eIF2, eIF2 $\alpha$, is one of the main targets for translation inhibition in the case of cellular stress and. as indicated previously represents the main PERK substrate. The phosphorylation of eIF $2 \alpha$ on serine then induces overall translational impairment but mRNAs encoding stress response proteins must be able to escape global translation repression induced by PERK-mediated eIF $2 \alpha$ phosphorylation, and many mechanisms have been developed to do so.

\subsection{Selective mRNA Translation during eIF2 Phosphorylation:}

\subsubsection{Regulation by $\mathrm{uORF}$}

Upstream Open Reading Frames: uORFs

uORFs represent one of the major regulatory motifs present in the $5^{\prime}$ UTR, which have been found to be involved in translational regulation under stressful conditions. In this context the repression imposed by uORFs on the initiation of translation of the main ORF is relieved, thus allowing the production of specific proteins in response to stress. The mode of action of each uORF appears dictated by its initiation codon context, secondary structure and coding capacities $[83,84]$. Moreover, the overall regulation of a given mRNA will depend on the specific combination and organisation of uORFs in its $5^{\prime}$ terminal region [85].

The precise mechanisms by which eIF $2 \alpha$ phosphorylation regulates the relative translation initiation efficiencies at uORFs and at their downstream protein-coding sequences remain not entirely clarified and may be diverse depending on the nucleotide sequence and relative organisation of the different translation initiation regions [85]. For some genes which exhibit preferential translation during ER stress, such as ATF4 and C/EBP $\beta$ it has been proposed that during stress the lowered eIF2-GTP level resulting from eIF2 $\alpha$ phosphorylation on Ser51 induces a reduction of the eIF2-GTP-met-tRNAi ternary complex intracellular concentration. This would delay the reacquisition of the ternary complex by the $40 \mathrm{~S}$ ribosome after the translation reinitiation, which follows the completion of uORF translation and allow the scanning ribosome to skip downstream additional inhibitory uORFs sequences. This mode of regulation has been widely accepted by scientists in the field and has been proposed to take place in other stress-regulated genes as well [85]. However, kinetic and stoechiometric data validating this mechanism are still missing. Furthermore, the nucleotide sequence around the start codon of the uORF also influences the efficiency of translation of the downstream sequence and it has been shown that mRNAs which are preferentially translated upon stress frequently contain uORFs with suboptimal Kozak consensus sequences [86]. The phosphorylation of eIF2 $\alpha$ on Ser51 may induce conformational changes, which impair initiation at AUG codons with suboptimal sequence context [87]. A decreased recognition of uORFs due to their unfavourable Kozak context has been proposed to be at least in part involved in the increase of expression of GADD34 [88] and CHOP $[89,90]$ during ER stress. 
It is currently assumed that the translation of uORFs is detrimental to the expression of the downstream coding sequences. These uORFs may exert their repressive effect by diverse, non-exclusive, mechanisms such as direct competition for translation initiation, translation elongation stall [89], and increased ribosome release for the translated mRNA [88]. In addition, uORFs could contribute to the inhibition of downstream CDS expression through mechanisms unrelated to mRNA translation initiation per se, such as increased mRNA decay [85,91]. However, a recent elegant research work demonstrated that most of the uORFs may actually remain translated during stress [92] and in addition that translational activation of the main coding sequence may involve at least in part specific translation initiation factors such as eIF2A [92]. Therefore, additional studies are still needed to fully elucidate the precise mechanisms of translational activation during ER stress.

A recent study illustrated well the relevance of investigating uORF in cancers. From different tumour samples, a screen based on a multiplex identifier-tagged deep sequencing, revealed $404 \mathrm{uORF}$ and two loss-of-function mutations in UORF in EPHB1 and MAP2K6. By luciferase- assay, the authors confirmed that the observed mutations lead to an increase of translation of the downstream reporter. In parallel, whole exome sequencing allows one to identify another 53 deleting mutations in uORF suggesting that uORF-associated mutations can contribute to rewire the translation in cancers [93].

\section{uORFs Translation upon ER Stress}

Some of the proteins that were shown to be upregulated through an uORF-dependent mechanism are known to play a central role in determining cell fate following stress induction. The ER chaperone $\mathrm{BiP} / \mathrm{Grp} 78$, a master regulator of ER stress signalling, contains $2 \mathrm{uORFs}$ encoded from non-canonical initiation codons and the translation of these ORFs, which involves at least in part the translation factor eIF2A, was found to be necessary for sustained BiP expression during stress and, therefore, general modulation of the stress signalling response [92]. The activating transcription factor 4 (ATF4) regulates the expression of a variety of cytoprotective genes acting in particular on amino acid metabolism and oxidative stress damage and which participate in the recovery of the cell from the injuries, which induced the stress response. ATF4 is however also involved in the activation of the transcription of CHOP (C/EBP Homologous Protein)/GADD153/DDIT3 [22,94,95], a transcription factor which when expressed to high levels can activate the transcription of a set of genes promoting caspase activation and cell death. On the other hand, ATF4 and CHOP both up-regulate the expression of GADD34 [96,97], an activatory subunit of the protein phosphatase 1 complex, which is involved in the dephosphorylation of $\alpha$ and resumption of translation. Moreover, the combined action of the ATF4 and CHOP transcription factors at the promoters of a set of genes involved in protein synthesis has also been found to contribute to the re-induction of global translation [98]. Reactivation of protein translation following stress may have opposing effects on cell viability depending on the cellular context. Whereas resumed translation will participate in cell recovery after stress-associated injuries have been repaired, increased protein translation can also lead to cell death resulting from ATP depletion and oxidative stress [98]. Therefore, the precise and timely-controlled expression of factors such as ATF4, CHOP, and GADD34 regulating global translation as well as repair of cell damage or entry into apoptosis is essential to the cell in order to adequately cope with the stress response.

Interestingly, the mRNAs coding for these different proteins have all been found to contain functional uORFs that inhibit their translation under normal conditions. Upon stress induction however the inhibition imposed by the uORFs on ATF4, CHOP, and GADD34 is strongly abrogated and this mostly contributes to the re-expression of these different factors in the cell. Two uORFs are present in the $5^{\prime}$ region of ATF4. The most downstream uORF overlaps with the ATF4 coding sequence and inhibits its translation in normal conditions and low eIF2 $\alpha$ phosphorylation $[99,100]$. A unique uORF encoding a specific peptide motif able to stall translation elongation and to inhibit CHOP translation in the absence of stress has also been identified in its mRNA [90]. The mRNA encoding GADD34 contains two uORFs. The most $5^{\prime}$ proximal sequence acts as a slight attenuator of GADD34 translation whereas 
the second uORF strongly inhibits downstream protein translation by likely promoting release of the ribosome from the mRNA after the uORF STOP codon has been reached $[88,101]$.

The recognition and translation of the uORF may however in some instances be required for the up-regulation of proteins during stress. This is the case for the C/EBP $\beta$ transcription factor, which is expressed as three different isoforms produced from translation events occurring at different initiation codons. The shortest C/EBP $\beta$ isoform (LIP: liver-enriched inhibitory protein) has been reported to interact as an heterodimer with the $\mathrm{CHOP}$ transcription factor and to be essential to its nuclear relocalisation and the activation of its target genes, resulting in the induction of apoptosis [102]. The highly increased production of LIP during sustained endoplasmic reticulum stress involves the translation of an UORF allowing the ribosome to skip the initiation codon of the following main C/EBP $\beta$ isoform (LAP: liver-enriched activatory protein) and start translation from the LIP initiation codon [103].

Additional proteins involved in the metabolic recovery of cells and whose expression is induced during stress through an uORF-dependent manner have been identified. For example, the aminoacyl tRNA synthetase EPRS is involved in the charging of tRNAs with glutamine and proline residues, therefore restoring the available glutamyl- and prolyl-tRNA intracellular pools. Two inhibitory uORFs initiated at non-canonical codons (CUG and UUG) have been identified in the EPRS mRNA and shown to reduce EPRS translation under normal conditions [104]. This inhibition is relieved during stress, leading to the re-accumulation of EPRS in the cell. The amino acid transporter Cat-1, which mediates the uptake of the essential amino acids arginine and lysine, is induced during ER stress by different complementary mechanisms [105]. In particular, the translation of an uORF has been shown to play an essential role in the re-expression of Cat- 1 by an original mechanism which involves the modification of the folding and reactivation of a cryptic IRES element in the 5'UTR of Cat-1 mRNA [106].

The currently available data strongly emphasise the essential role played by the upstream ORFs in the translational control of genes involved in the recovery from cell injuries and in the regulation of the stress response itself. Whatever the mechanisms operating, the uORF-dependent regulation of translation appears tightly controlled by the intracellular levels of phospho ${ }^{51}$-eiIF $2 \alpha$, which can be rapidly modulated during the stress response. It therefore represents a highly sensitive and responsive mean to regulate specific protein expression under stress conditions. Mutations affecting the activity of uORF and consequently the translation of the downstream ORF have been reported in different cancer models [83]. It is likely that uORFs mutations could as well affect the expression of stress-regulated factors and favour some cancer-associated processes but this has still not been reported to date.

\subsubsection{Cap-Independent Translation Regulation}

\section{IRES-Dependent Translation Initiation}

In the early 80 s, the cap-dependent mechanism was believed to be the only possible mechanism of translation initiation in eukaryotic cells. An alternative route that bypasses the initial cap-recognition, allowing ribosomal recruitment to internal locations in mRNA, termed internal ribosome entry sites (IRESs) was however revealed more than 30 years ago (Figure 2B) [107-109]. The IRESs were first discovered in the late 1980s in studies on poliovirus [108,110], whose characteristics are incompatible with cap-dependent translation initiation and encephalomyocarditis virus (EMCV) [109]. Indeed, poliovirus mRNA is naturally uncapped and the virus itself interferes with the cellular translation by proteolytic degradation of the cap-binding proteins, implicating that poliovirus mRNAs must be translated by cap-independent mechanisms. Many groups confirmed this notion for example by showing, through means of mutagenesis, that an internal sequence in the $5^{\prime}$ UTR of poliovirus RNA was responsible for its cap-independent translation and this sequence could also confer cap-independent translation to heterologous mRNAs [108-111]. During the same years, a cellular mRNA, encoding glucose-regulated protein 78 (GRP78)/immunoglobulin heavy-chain binding protein (BiP), was found to be translated at an increased rate in poliovirus-infected cells, while cap-dependent 
translation was inhibited [107], showing for the first time that translation initiation by an internal ribosome-binding mechanism was used by eukaryotic mRNAs [112,113]. Since that time, many viral and cellular IRESs have been reported and recorded in the IRESite database [114]. More recently, the existence of IRES elements in cellular mRNAs was investigated using a high throughput strategy, which highlighted the existence of thousands of sequences, allowing cap-independent translation, and showed that $10 \%$ of mRNAs could potentially be translated by a cap-independent mechanism [115]. Interestingly, many IRES-containing mRNAs encode proteins that are involved in proliferation, differentiation, and apoptosis and can be translated when the overall cellular protein synthesis is inhibited upon different stress conditions, including ER stress, apoptosis, viral infection, nutrient starvation and hypoxia [116] generating ongoing interest in the field of protein translation and its regulation.

Despite a growing list of IRES-containing mRNAs, the mechanism of internal initiation is still poorly understood. Given that many IRESs have been identified in conditions of inhibited cap-dependent initiation, the cap-binding protein eIF4E and the scaffolding protein eIF4G do not seem to be required for IRES-mediated translation $[107,117]$, although, it has been reported that, for example, MYCL IRES requires both eIF4E and eIF4G for its translation [117]. Curiously, homologs of eIF4G, such as eIF4G1, eIF4G2 [113,118] and DAP5/p97 [118,119], are shown to be associated with polysomes in poliovirus-infected cells and, at the same time, to be required for the IRES-mediated translation of selected mRNAs following cellular stress [119], implicating that eIF4G proteins are needed in both $5^{\prime}$ cap-independent and $5^{\prime}$ cap-dependent translational initiation mechanisms. Finally, the activity of the RNA helicase eIF4A seems to be essential for the translation of MYC, MYCN [120] and BIP IRESs [121]. The role of eIF2 has also been investigated for cellular internal initiation. Importantly, IRES-mediated mRNAs translation can operate upon global protein synthesis attenuation induced by eIF2 phosphorylation [116,122-127]. In addition to the involvement of canonical initiation factors, efficient IRES-dependent translation requires auxiliary RNA-binding proteins, known as IRES trans-acting factors (ITAFs; Figure 2B) [128]. The mechanism of ITAF function is not fully understood, but it is generally believed that many ITAFs are required for the stabilisation of IRES conformation. Importantly, the subcellular localisation of ITAFs have been shown to be crucial for their function [128] (described below). Examples of ITAFs include La autoantigen [129] and several heterogeneous nuclear riboproteins (hnRNP) such as hnRNPC1/C2 [130] and hnRNPA1 [123,131].

One of the most relevant examples highlighting IRES importance in cancers is the MYC IRES in multiple myeloma. Indeed, a point mutation in this specific IRES sequence was identified in $42 \%$ of patient bone marrow samples [132]. This mutation enhances the translation of the proto-oncogene MYC suggesting that IRES deregulation could be responsible for overexpression of oncogenes. In silico analysis fail to reveal IRES that need to be functionally tested in-vitro, which render their identification laborious hence the list of IRES is still limited. However, IRESs have already been described in many other mRNAs encoding proteins involved in tumourigenesis and cell survival (Apaf-1, cJUN, AML1/Runx1, EGFR/HER1, BCL2, BCL-XL, XIAP, MYC, MYCN, VEGF-A, P27, P53), suggesting that IRES-mediated translation play a crucial role in tumour progression and survival [133]. Direct evidence that supports this hypothesis comes from many studies. For example, 3D spheroids culture of ovarian cancer cells treated with a PI3K/mTOR inhibitor reveals resistant cells expressing BCL2, which is indeed translated by a cap-independent mechanism in these conditions [134]. IRESs mediated translation also promotes inflammatory breast cancer tumour cell survival and formation of tumour emboli by activating p120 catenin mRNAs expression [135]. Another example concerns the P53 protein, which is also translated by a cap-independent mechanism due to the presence of two IRES residing within the $5^{\prime}$ UTR and the coding sequence $[136,137]$. These IRES, activated in response to DNA damage, binds several ITAFs including DAP5 (or p97 or NAT1) which is a member of the eIF4G proteins, the translational control protein 80 (TCP80), Ribosomal protein L26 (RPL26) and nucleolin [138-140]. If these proteins are either over or underexpressed in the cells, or if mutations affect p53 mRNA IRES structure, p53 protein level can fluctuate [136,141]. Thus, some wild type p53-expressing cancer cells 
may not express p53 due to an IRES-dependent defective translation demonstrating the key role of IRES-mediated translation initiation in cancer development.

IRES Regulation in Response to Stress

Even if cellular IRESs have been described in a limited, but growing, number of mRNAs, many genes involved in stress response, such as HSPA5, ATF4, HIF1 $\alpha$, NRF2, FGF-2, VEGF-A, VEGF-C, STAUFEN or DLL4 are thought to contain IRESs [123,142-151].

Several master regulators of the UPR can be translated by a cap-independent mechanism. Remarkably, the BiP transcript was the first cellular mRNA reported to contain an IRES [112]. Moreover, ATF4 translation is regulated by either uORFs or an IRES. Indeed, an alternatively spliced variant of ATF4, expressed in leukocytes and induced by UPR, is translated by a cap-independent mechanism, which is activated by PERK-mediated eIF $2 \alpha$ phosphorylation [152]. The presence of these elements therefore allows these mRNAs to be efficiently translated in stress conditions.

PERK activation also results in an IRES-dependent activation of TP53 isoform translation [153]. It has been demonstrated that two TP53 isoforms, TP53 and TP53/47, are translated by two different IRESs located on the same mRNA [137,154]. In stressful situations, an increase of the TP53/47 isoform-dependent IRES translation results in a cell cycle arrest in the G2 phase, while the full length TP53 induces a G1 phase arrest [153,154].

Cellular IRESs are often found in long and GC-rich structured 5'UTRs, and are relatively ineffective in directing translation under physiological conditions. However, the precise molecular mechanism of cellular IRES-directed translation in stress conditions when eIF $2 \alpha$ phosphorylation is not completely understood.

Stabilisation of secondary structures, for example through interaction with proteins, could slow down the scanning of the $43 \mathrm{~S}$ pre-initiation complex and thus promote translation re-initiation efficiency [155]. According to the "land and scan" initiation model used by the already characterised cellular IRESs, the $40 \mathrm{~S}$ subunit lands at the IRES before scanning from $5^{\prime}$ to $3^{\prime}$ to the initiation codon [156-158]. Since IRESs are highly structured elements, one hypothesis is that these elements could represent a barrier that would slow down ribosome progression, thus explaining the increase in IRES-dependent translation under eIF $2 \alpha$ phosphorylation conditions. In the same way, these structures, potentially bound by proteins, may also be pause sites allowing the ribosome to recruit active initiating factors, thus stimulating translation when eIF $2 \alpha$ is phosphorylated.

As previously mentioned, most IRESs, require ITAFs for their regulation [159]. The expression and the activity of these ITAFs can be modulated by UPR. For example, under ER stress, caspase-12 cleavage of the ITAF eIF4G2 (DAP5/p97) produces a fragment known as p86 [160] enhancing the IRES-mediated translation of HIAP2 (human apoptosis protein 2 inhibitor) Apaf-1 and XIAP [161,162] leading to the reduction of apoptosis and allowing the UPR to cope with stress [163].

Subcellular relocalisation of ITAFs plays also a crucial role in the modulation of IRES-dependent translation efficiency [128]. This is the case of hnRNPA1, which is relocalised from the nucleus to the cytoplasm during ER stress [131]. Moreover, hnRNPA1 cytoplasmic accumulation requires eIF2 $\alpha$ phosphorylation [164], and was shown to modulate IRES-dependent translation of SREBP-1a, c-MYC or DLL4 in response to endoplasmic reticulum stress [123,131,165].

Such relocation has also been documented for other ITAFs, including PTB and PCBP1 (poly r(C) 1 binding protein or hnRNPE), which work jointly to activate BAG1 IRES (Bcl-2 Associated with Athanogen 1) following chemotoxic stress [166]. Nucleolin is also translocated from the nucleolus to the cytoplasm and activates the VEGF-D IRES-dependent translation in response to heat shock [167]. Interestingly both chemotoxic stress and heat shock are known to activate the UPR. 
The Angiogenesis Paradigm

Angiogenesis is critical for many physiological processes, such as embryonic development and wound healing, but also in pathological states including the development of solid tumours.

As previously indicated, more than 100 mammalian mRNAs harbour IRESs in their $5^{\prime}$ UTRs. Interestingly, these mRNA include many mRNA encoding proteins strongly involved in the angiogenic process like VEGF-A, VEGF-C, VEGF-D, FGF-2, HIF1 $\alpha$, DLL4 or TSP1 [123,142,148,167-171]. Angiogenesis depends on the highly coordinated action of a variety of angiogenic regulators, the most prominent and best characterised being Vascular Endothelial Growth Factor A (VEGF-A), Fibroblast Growth Factor 2 (FGF-2) and DLL4. Indeed, DLL4 is with VEGFA one of the few examples of haplo-insufficiency, resulting in obvious vascular abnormalities and in embryonic lethality [172-174].

It was already demonstrated that VEGF-A, FGF-2 and DLL4 IRESs are activated upon stress conditions including hypoxia or ER stress and that these mRNAs remain efficiently translated under ER stress conditions despite phosphorylation of the major PERK substrate, eIF2 $\alpha[123,124,142,168]$.

These results are consistent with the fact that tumours derived from K-Ras-transformed Perk ${ }^{-1-}$ MEFs (mouse embryonic fibroblasts) display less angiogenesis and grow less rapidly than tumours with an intact UPR signalling [175], demonstrating the role of PERK activation in the angiogenic process.

The presence of IRESs in many mRNAs encoding proteins tightly involved in the angiogenic process enables a selective co-regulation of these mRNAs expression under stress conditions (Figure 3). The tumour microenvironment is composed of a set of tumour and stromal cells and extracellular matrix. During tumour progression, impaired vascularisation causes several stresses including hypoxia, glucose or amino acid starvation or acidosis. These unfavorable conditions are known to induce ER stress, phosphorylation of eIF $2 \alpha$ and thus activation of a gene network dependent on this phosphorylation in the stress area surrounding the tumour. Consequently, mRNAs encoding VEGF-A, -C, -D, FGF-2, HIF1A or DLL4 that are expressed by tumour cells or microenvironment (such as DLL4 expressed by TIP cells which are furthest away from the circulating blood are still efficiently translated while cap-dependent initiation is compromised (Figure 3). IRES therefore function as cis-acting regulons during ER stress.

These results demonstrate that for cancer to progress under stressful conditions, it must use alternative translation mechanisms, such as IRES-dependent translation, to promote angiogenesis and thus survival and growth. 


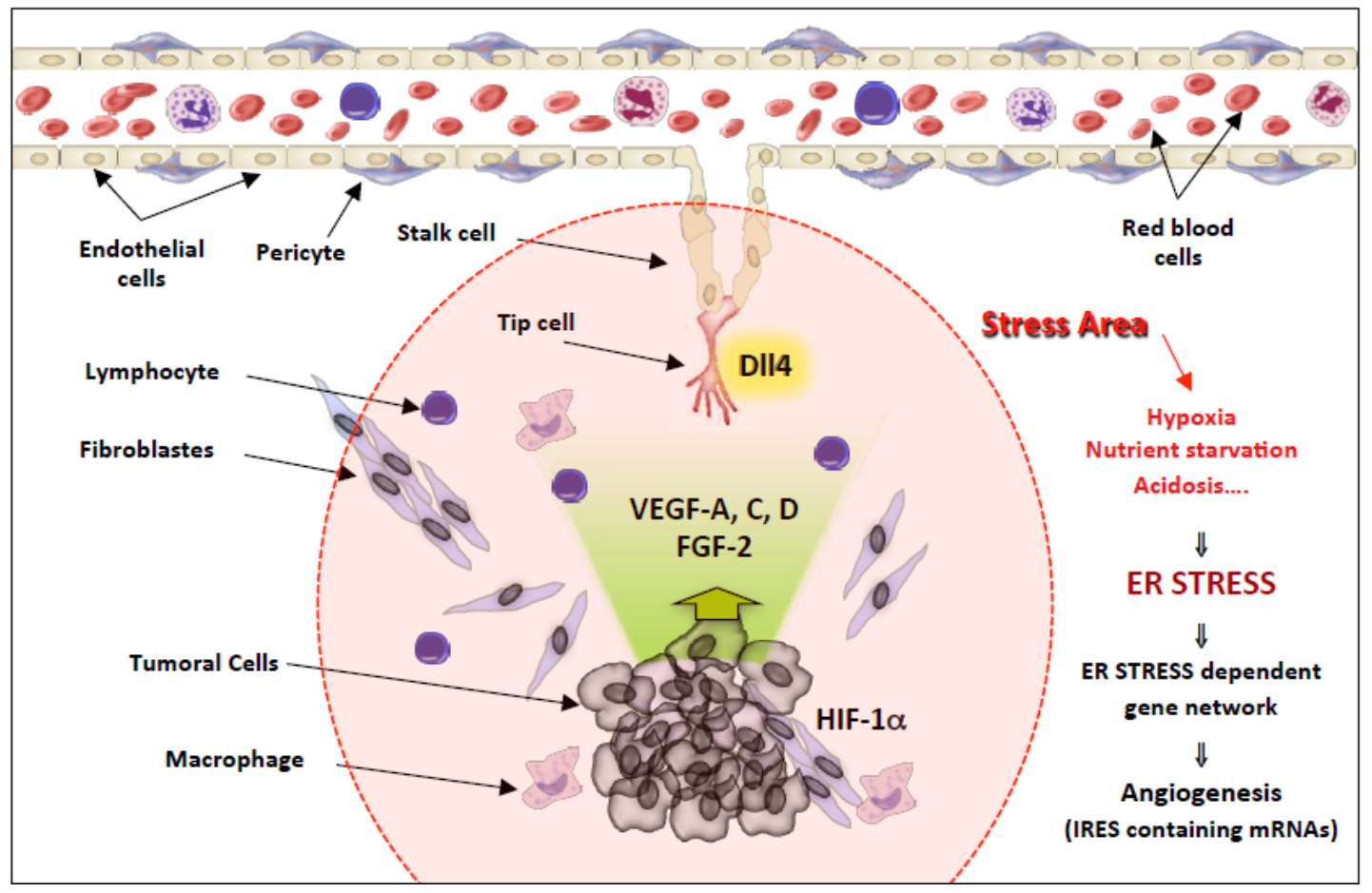

Figure 3. Schematic model of the network of gene expression co-regulation by IRES elements in stress conditions during tumoural progression. During tumour progression, the stress zone encompasses the growing tumour, but also its microenvironment. Both the tumour and the neo vessels, more particularly the Tip cells located at their extremity, which guide the neo vessels towards the tumour, are located in this unfavourable microenvironment. Hypoxia, nutrient starvation, and acidosis will irremediably induce the accumulation of unfolded protein in the reticulum of cells located in this area, leading to endoplasmic reticulum stress and UPR activation. Thus, in addition to transcriptional regulations, the activation of the PERK pathway will induce the co-regulation an UPR-dependent gene network containing IRES elements, revealing a translational regulon in which the synthesis of a cohort of angiogenic master regulator genes including VEGF-A,C,D, FGF-2, DLL4, and HIF1 is activated in response to ER stress. The fine-tuning of gene expression allows for efficient angiogenesis, which is a highly regulated process.

\section{4. mRNA Translational Control by IRE1 under ER Stress}

Even if it is much more anecdotal, several studies have proposed that IRE1 also participates in translation repression during ER stress.

First of all, IRE1 selectively suppresses secretory protein translation by targeting mRNAs through RIDD to alleviate the load on the protein folding machinery. As indicated previously, a few dozens of mRNAs are known to be targeted by IRE1. Even if a consensus cleavage site embedded in a stem loop structure has been identified in vitro $[37,176,177]$, it remains particularly difficult to predict the direct RIDD targets. The question arises of how these RIDD mRNA targets are addressed to the reticulum membrane. Indeed, most but not all these mRNAs encode proteins with signal peptide/transmembrane domains [36]. It was demonstrated that the removal of the signal peptide from a known RIDD target impedes its degradation and, inversely, introduction of a signal peptide to the GFP mRNA is sufficient to favour its degradation by IRE1 [178]. However, the question of the targeting of messenger RNAs that do not code for secreted or membrane proteins remains open. Alternative mechanisms could, for example, involve specific RNA-binding proteins. It is, however, important to mention that mRNAs encoding cytoplasmic proteins are also found at the membrane of the ER $[179,180]$. In addition, ribosome-profiling experiments combined with subcellular fractionation demonstrated that ER-associated mRNAs encoding both cytosolic proteins and those encoding secreted/membrane proteins display similar ribosome loading densities [181]. These data, 
therefore, suggest that ER-associated ribosomes would play a major role in the translation of both mRNAs encoding cytoplasmic or secreted proteins. On the other hand, the co-activation of PERK and IRE1 pathways appears to be essential to the RIDD mechanism. Indeed, it has been shown that PERK depletion decreases the degradation of some mRNA targets while artificial translation blockage restores the RIDD. To explain these results, a possible hypothesis is that translation by ribosomes disturbs the stem loop structure recognised and cleaved by IRE1. Thus, the correct recognition of the target RNA would require a translation blockade by PERK or eventually a translational pause [182].

In glioma cells, IRE1 has been described to target the mRNA encoding the extracellular matrix protein SPARC. Downregulation of SPARC by IRE1 leads to a modulation of stress fibre formation and enhances migration properties of glioma cells [41]. Another substrate of the RIDD is PER1 mRNA, a circadian clock gene that controls the expression of CXCL3, an important chemokine involved in cancer development [40]. IRE1 has also been reported to protect cells from apoptosis, notably, through the decay of the death receptor 5 (DR5) mRNA. These few examples among the increasing list of RIDD targets highlight the pivotal role of this IRE1 downstream pathway in cancer [43].

IRE1 can also modulate the translation by another mechanism. Indeed, it was demonstrated that overexpression of IRE1 $\beta$ induces 28 S rRNA cleavage [183] more efficiently than IRE1 $\alpha$ [184]. In this inducible hIRE1 $\beta$ expression model, total protein synthesis was repressed by $30 \% 1$ day after hIRE1 $\beta$ induction. Thus, the cleavage of $28 \mathrm{~S}$ RNA could reduce the number of functional ribosomes. As it was demonstrated that reduced ribosome levels impaired the translation of transcripts that are normally efficiently translated and have short and unstructured 5'UTRs in comparison to other transcripts [185], this mechanism could enable the specific modulation of expression of certain messenger RNAs.

Finally, a subset of RNAs including ER-targeted mRNAs, SRP RNA, ribosomal and transfer RNAs were demonstrated to physically associate with IRE1 in living cells [186]. Moreover, IRE1 interacts with the translocon, the translocon-associated TRAP component, SRP proteins and ribosomal proteins [32]. IRE1 also strongly binds $80 S$ ribosomes in vitro [186]. These results show that IRE1 is closely coupled to the translation machinery, but the precise functions of these different interactions are not yet clearly identified.

Although post-transcriptional gene regulation mediated by the IRE1 proteins has received a lot of attention in recent years, our understanding of the role of IRE1 in translational regulation is still in its early days.

\section{5. mRNA Structures and Modifications Regulate Translation:}

\subsection{1. eIF3 Recruitment by RNA Structures}

The multisubunit initiation factor eIF3 (13 subunits eIF3a-m) plays a central role in the cap-dependent translation initiation through its interaction with eIF4G, which allows the recruitment of the $43 S$ pre-initiation complex [187]. However, eIF3 can also interact with mRNA stem loop structures in the $5^{\prime}$ UTR and directly regulate both cap-dependent and independent translation. eIF3 plays an essential role in translation of specific subsets of mRNA [188]. Indeed, Lee et al., reported that eIF3 uses different modes of mRNA stem loop binding to exert positive and negative translation regulation of key proliferative transcription factors such as cJUN and BTG1 [188]. Using PAR-CLiP (photoactivatable ribonucleoside-enhanced crosslinking and immunoprecipitation) technology, they showed that eIF3 interacts with $3 \%$ of the expressed transcripts through direct interactions of mRNA with the eIF3 subunits $a, b, d$ and $g$. The binding of the cap by the eIF3d subunit in presence of the stem loop in the 5'UTR allows to bypass the canonical eIF4E translation and initiate an eIF3d-directed cap-dependent mRNA translation (Figure 2C) [189].

Different viruses seem to exploit the capacity of eIF3 to initiate translation. The hepatitis C virus harbours an IRES whose direct interaction with eIF3 is critical to induce efficient translation initiation [190]. The positive strand RNA virus, Barley Yellow Dwarf Virus (BYDV, Genus Luteovirus) 
employs a cap-independent mechanisms where eIF3 bridges the mRNA $5^{\prime}$ and $3^{\prime} \mathrm{UTR}$ to initiate and regulate its translation [191].

There is still limited evidence of a role of this eiF3-dependent translation regulation mechanism under ER conditions. For example, it was demonstrated that mutations in eIF3k and eIF31 genes enhanced resistance to ER stress in Caenorhabditis elegans [192]. Moreover, UV crosslink experiments reveal that activation of ER stress by thapsigargine treatment results in a marked increase of several eIF3 subunits binding to polyadenylated mRNAs [193]. This work also demonstrates that eIF3 subunits favour the recruitment of selected mRNAs to $40 \mathrm{~S}$ ribosomes during chronic ER and that this chronic stress renders eIF3 as the key mediator of mRNA recruitment to the PIC [193]. Taken together, even though the molecular mechanisms are still unknown, these data suggest a critical functional role for these eIF3 subunits in the regulation of cellular responses to ER stress.

\subsection{2. m6A-Dependent Translation Initiation}

In addition to secondary mRNA structures, specific RNA modifications may have a strong impact on alternative translation mechanisms. For instance, a single $\mathrm{N}(6)$-methyladenosine $(\mathrm{m}(6) \mathrm{A})$ residue in the $5^{\prime}$ UTR promotes cap-independent mRNA translation initiation, through direct interaction with eIF3 which is sufficient to recruit the $43 \mathrm{~S}$ complex and initiate translation even in the absence of the cap-binding factor eIF4E [194] (Figure 2D).

$\mathrm{N}(6)$-methyladenosine modification is the most abundant post-transcriptional mRNA modification $[195,196]$, it exhibits tissue-specific regulation with an enrichment of $\mathrm{m}(6)$ A sites near stop codons and in 3'UTRs [197,198]. The methylation and demethylation of mRNA adenosine is dictated by "writers" and "readers" (reviewed by [199]). The intracellular fate of methylated mRNA is under the control of "readers" which according to their abundance, localisation (nucleus vs. cytoplasm), or the presence of specific RNA binding proteins (RBPs) will determine mRNA decay, stability or translation $[187,199]$. Thus, three readers-YTHDF1, YTHDF3, and YTHDC2—are heavily involved in translation of m(6)A mRNA [200-202]. YTHDF1 selectively recognises m(6)A 3' UTR modified mRNA, promotes ribosome loading and interacts with different subunits of eIF3 complex to facilitate translation initiation [202]. YTHDF3 promotes protein synthesis in synergy with YTHDF1 and affects methylated mRNA decay mediated through YTHDF2 ("reader" involved in mRNA decay). However, it is still unclear if the processes require direct interaction between the different YTH proteins or the cooperation of co-factors [201]. While decreasing the abundance of m(6)A 3'UTR modified mRNAs, YTHDC2 also enhances their translation efficiency. The authors suggested that YTHDC2 may increase the translation of transcripts, and then destabilise the transcripts after translation has been completed to prevent further differentiation of cells [200].

Interestingly while METTL3 is a m(6)A "writer" in the nucleus, it functions as a potential "reader" when localised in the cytoplasm where it enhances translation of m(6)A mRNA through interaction with eIF3h (Figure 2E). METTL3 has also been proposed to promote oncogene translation through a mRNA looping mechanism [203,204]. In addition, promoter-bound METTL3 can induce m(6)A modification within the coding region of the associated mRNA transcripts, and enhance its translation by relieving ribosome stalling [205].

Although N6-methyladenosine marks on mRNA are preferentially located in the 3'UTR [197], diverse cellular stresses can induce a wide redistribution of m(6)A transcriptome marks, resulting in increased numbers of mRNAs with $5^{\prime}$ UTR m(6)A [194]. For instance, heat shock stress induces preferential m(6)A deposition at the $5^{\prime} \mathrm{UTR}$ of newly transcripts. In the nucleus, under such stress, YTHDF2 preserves 5'UTR methylation of stress-induced transcripts by limiting the m(6)A "eraser" FTO activity. This mechanism allows the cap-independent translation of stress mRNA such as Hsp70 [198]. Moreover, it was already reported that m(6)A could recruit eIF3 to induce 48S initiation complex formation independent of eIF4E cap binding [194] especially under heat shock conditions when cap-dependent initiation is blocked, and also that m(6)A-based regulation contributed to the translational control of ATF4 during amino acid starvation [206]. A correlation between increased 
local m(6)A modification and usage of non-canonical start codons during amino acid starvation was also described, which increase further the complexity of translation regulation mechanisms in stress conditions [206]. Even though the reversible m6A RNA methylation process has been now widely described, the cellular functions of this modification remain largely unclear, and further studies will be required to clarify the role of this modification in translational regulation, specifically during ER stress.

\section{Conclusions}

Protein translation regulation is an essential mechanism to maintain the cell's integrity and enable it to cope with stresses. Protein synthesis is not a single process, but a combination of several different mechanisms that finely regulate the expression of specific mRNAs in response to stress in order to quickly adapt the cellular proteome.

Upon ER stress and eIF2 $\alpha$ phosphorylation by PERK, cancer cells use alternative translation mechanisms that are mediated by cis-acting sequences, such as UORF and IRES, to drive the expression of specific mRNA subsets involved in the stress response. Even if translational regulation mediated by uORF and IRES during stress response is well documented, these alternative mechanisms of translation are not yet fully understood.

Thus, even if the knowledge of translational regulations has grown considerably during the past few years, thanks in part to recent technological advances in profiling genome-wide translation, strong efforts must be made in order to better understand the molecular mechanisms underlying translational control in cancer during the stress response. In addition, we believe that a better understanding of the mechanisms allowing the selective translation of specific mRNAs in stress conditions could also lead to the identification of new targets and holds great promise for novel therapeutics in oncology.

Funding: This work was supported the Institut National de la Santé et de la Recherche Médicale (INSERM), Université Toulouse III (Paul Sabatier) and by grants from the Kay Kendall Leukaemia Fund (KKL1149 awarded to KRP), Academy of Medical Sciences (AMS 7SBF004/1099 awarded to KRP), Queen Mary University of London (awarded to KRP), Association Laurette Fugain (ALF2018/03 awarded to CT). CP and MJ were supported by a fellowship from the French ministry of higher education and research.

Conflicts of Interest: The authors declare no conflict of interest.

\section{References}

1. Reid, D.W.; Nicchitta, C.V. Diversity and selectivity in mRNA translation on the endoplasmic reticulum. Nat. Rev. Mol. Cell Biol. 2015, 16, 221-231. [CrossRef]

2. Ron, D.; Walter, P. Signal integration in the endoplasmic reticulum unfolded protein response. Nat. Rev. Mol. Cell Biol. 2007, 8, 519-529. [CrossRef]

3. Hetz, C. The unfolded protein response: Controlling cell fate decisions under ER stress and beyond. Nat. Rev. Mol. Cell Biol. 2012, 13, 89-102. [CrossRef]

4. Dejeans, N.; Manie, S.; Hetz, C.; Bard, F.; Hupp, T.; Agostinis, P.; Samali, A.; Chevet, E. Addicted to secrete -Novel concepts and targets in cancer therapy. Trends Mol. Med. 2014, 20, 242-250. [CrossRef]

5. Khan, M.M.; Nomura, T.; Chiba, T.; Tanaka, K.; Yoshida, H.; Mori, K.; Ishii, S. The fusion oncoprotein PML-RARalpha induces endoplasmic reticulum (ER)-associated degradation of N-CoR and ER stress. J. Biol. Chem. 2004, 279, 11814-11824. [CrossRef]

6. Kriss, C.L.; Pinilla-Ibarz, J.A.; Mailloux, A.W.; Powers, J.J.; Tang, C.H.; Kang, C.W.; Zanesi, N.; Epling-Burnette, P.K.; Sotomayor, E.M.; Croce, C.M.; et al. Overexpression of TCL1 activates the endoplasmic reticulum stress response: A novel mechanism of leukemic progression in mice. Blood 2012, 120, 1027-1038. [CrossRef]

7. Senovilla, L.; Vitale, I.; Martins, I.; Tailler, M.; Pailleret, C.; Michaud, M.; Galluzzi, L.; Adjemian, S.; Kepp, O.; Niso-Santano, M.; et al. An immunosurveillance mechanism controls cancer cell ploidy. Science 2012, 337, 1678-1684. [CrossRef]

8. Hetz, C.; Glimcher, L.H. Fine-tuning of the unfolded protein response: Assembling the IRE1alpha interactome. Mol. Cell 2009, 35, 551-561. [CrossRef] 
9. Kaufman, R.J. Stress signaling from the lumen of the endoplasmic reticulum: Coordination of gene transcriptional and translational controls. Genes Dev. 1999, 13, 1211-1233. [CrossRef]

10. Higa, A.; Taouji, S.; Lhomond, S.; Jensen, D.; Fernandez-Zapico, M.E.; Simpson, J.C.; Pasquet, J.M.; Schekman, R.; Chevet, E. Endoplasmic reticulum stress-activated transcription factor ATF6alpha requires the disulfide isomerase PDIA5 to modulate chemoresistance. Mol. Cell Biol. 2014, 34, 1839-1849. [CrossRef]

11. Eletto, D.; Eletto, D.; Dersh, D.; Gidalevitz, T.; Argon, Y. Protein disulfide isomerase A6 controls the decay of IRE1alpha signaling via disulfide-dependent association. Mol. Cell 2014, 53, 562-576. [CrossRef] [PubMed]

12. Sepulveda, D.; Rojas-Rivera, D.; Rodriguez, D.A.; Groenendyk, J.; Kohler, A.; Lebeaupin, C.; Ito, S.; Urra, H.; Carreras-Sureda, A.; Hazari, Y.; et al. Interactome Screening Identifies the ER Luminal Chaperone Hsp47 as a Regulator of the Unfolded Protein Response Transducer IRE1alpha. Mol. Cell 2018, 69, 238-252 e237. [CrossRef] [PubMed]

13. Karagoz, G.E.; Acosta-Alvear, D.; Nguyen, H.T.; Lee, C.P.; Chu, F.; Walter, P. An unfolded protein-induced conformational switch activates mammalian IRE1. eLife 2017, 6. [CrossRef] [PubMed]

14. Hetz, C.; Papa, F.R. The Unfolded Protein Response and Cell Fate Control. Mol. Cell 2018, 69, $169-181$. [CrossRef] [PubMed]

15. Chevet, E.; Hetz, C.; Samali, A. Endoplasmic reticulum stress-activated cell reprogramming in oncogenesis. Cancer Discov. 2015, 5, 586-597. [CrossRef]

16. Thuerauf, D.J.; Marcinko, M.; Belmont, P.J.; Glembotski, C.C. Effects of the isoform-specific characteristics of ATF6 alpha and ATF6 beta on endoplasmic reticulum stress response gene expression and cell viability. J. Biol. Chem. 2007, 282, 22865-22878. [CrossRef]

17. Yamamoto, K.; Sato, T.; Matsui, T.; Sato, M.; Okada, T.; Yoshida, H.; Harada, A.; Mori, K. Transcriptional induction of mammalian ER quality control proteins is mediated by single or combined action of ATF6alpha and XBP1. Dev. Cell 2007, 13, 365-376. [CrossRef]

18. Shen, J.; Chen, X.; Hendershot, L.; Prywes, R. ER stress regulation of ATF6 localization by dissociation of BiP/GRP78 binding and unmasking of Golgi localization signals. Dev. Cell 2002, 3, 99-111. [CrossRef]

19. Yamamoto, K.; Yoshida, H.; Kokame, K.; Kaufman, R.J.; Mori, K. Differential contributions of ATF6 and XBP1 to the activation of endoplasmic reticulum stress-responsive cis-acting elements ERSE, UPRE and ERSE-II. J. Biochem. 2004, 136, 343-350. [CrossRef]

20. Adachi, Y.; Yamamoto, K.; Okada, T.; Yoshida, H.; Harada, A.; Mori, K. ATF6 is a transcription factor specializing in the regulation of quality control proteins in the endoplasmic reticulum. Cell Struct. Funct. 2008, 33, 75-89. [CrossRef]

21. Yoshida, H.; Okada, T.; Haze, K.; Yanagi, H.; Yura, T.; Negishi, M.; Mori, K. ATF6 activated by proteolysis binds in the presence of NF-Y (CBF) directly to the cis-acting element responsible for the mammalian unfolded protein response. Mol. Cell Biol. 2000, 20, 6755-6767. [CrossRef]

22. Ma, Y.; Brewer, J.W.; Diehl, J.A.; Hendershot, L.M. Two distinct stress signaling pathways converge upon the CHOP promoter during the mammalian unfolded protein response. J. Mol. Biol. 2002, 318, 1351-1365. [CrossRef]

23. Yoshida, H.; Matsui, T.; Yamamoto, A.; Okada, T.; Mori, K. XBP1 mRNA is induced by ATF6 and spliced by IRE1 in response to ER stress to produce a highly active transcription factor. Cell 2001, 107, 881-891. [CrossRef]

24. Schewe, D.M.; Aguirre-Ghiso, J.A. ATF6alpha-Rheb-mTOR signaling promotes survival of dormant tumor cells in vivo. Proc. Natl. Acad. Sci. USA 2008, 105, 10519-10524. [CrossRef]

25. Iwawaki, T.; Akai, R.; Yamanaka, S.; Kohno, K. Function of IRE1 alpha in the placenta is essential for placental development and embryonic viability. Proc. Natl. Acad. Sci. USA 2009, 106, 16657-16662. [CrossRef]

26. Bertolotti, A.; Wang, X.; Novoa, I.; Jungreis, R.; Schlessinger, K.; Cho, J.H.; West, A.B.; Ron, D. Increased sensitivity to dextran sodium sulfate colitis in IRE1beta-deficient mice. J. Clin. Investig. 2001, 107, 585-593. [CrossRef]

27. Martino, M.B.; Jones, L.; Brighton, B.; Ehre, C.; Abdulah, L.; Davis, C.W.; Ron, D.; O’Neal, W.K.; Ribeiro, C.M. The ER stress transducer IRE1beta is required for airway epithelial mucin production. Mucosal Immunol. 2013, 6, 639-654. [CrossRef]

28. Urano, F.; Bertolotti, A.; Ron, D. IRE1 and efferent signaling from the endoplasmic reticulum. J. Cell Sci. 2000, $113,3697-3702$. 
29. Urano, F.; Wang, X.; Bertolotti, A.; Zhang, Y.; Chung, P.; Harding, H.P.; Ron, D. Coupling of stress in the ER to activation of JNK protein kinases by transmembrane protein kinase IRE1. Science 2000, 287, 664-666. [CrossRef]

30. Peschek, J.; Acosta-Alvear, D.; Mendez, A.S.; Walter, P. A conformational RNA zipper promotes intron ejection during non-conventional XBP1 mRNA splicing. EMBO Rep. 2015, 16, 1688-1698. [CrossRef]

31. Lu, Y.; Liang, F.X.; Wang, X. A synthetic biology approach identifies the mammalian UPR RNA ligase RtcB. Mol. Cell 2014, 55, 758-770. [CrossRef]

32. Plumb, R.; Zhang, Z.R.; Appathurai, S.; Mariappan, M. A functional link between the co-translational protein translocation pathway and the UPR. eLife 2015, 4. [CrossRef]

33. Yanagitani, K.; Imagawa, Y.; Iwawaki, T.; Hosoda, A.; Saito, M.; Kimata, Y.; Kohno, K. Cotranslational targeting of XBP1 protein to the membrane promotes cytoplasmic splicing of its own mRNA. Mol. Cell 2009, 34, 191-200. [CrossRef]

34. Yanagitani, K.; Kimata, Y.; Kadokura, H.; Kohno, K. Translational pausing ensures membrane targeting and cytoplasmic splicing of XBP1u mRNA. Science 2011, 331, 586-589. [CrossRef]

35. Acosta-Alvear, D.; Zhou, Y.; Blais, A.; Tsikitis, M.; Lents, N.H.; Arias, C.; Lennon, C.J.; Kluger, Y.; Dynlacht, B.D. XBP1 controls diverse cell type- and condition-specific transcriptional regulatory networks. Mol. Cell 2007, 27, 53-66. [CrossRef]

36. Hollien, J.; Weissman, J.S. Decay of endoplasmic reticulum-localized mRNAs during the unfolded protein response. Science 2006, 313, 104-107. [CrossRef]

37. Han, D.; Lerner, A.G.; Vande Walle, L.; Upton, J.P.; Xu, W.; Hagen, A.; Backes, B.J.; Oakes, S.A.; Papa, F.R. IRE1alpha kinase activation modes control alternate endoribonuclease outputs to determine divergent cell fates. Cell 2009, 138, 562-575. [CrossRef]

38. So, J.S.; Hur, K.Y.; Tarrio, M.; Ruda, V.; Frank-Kamenetsky, M.; Fitzgerald, K.; Koteliansky, V.; Lichtman, A.H.; Iwawaki, T.; Glimcher, L.H.; et al. Silencing of lipid metabolism genes through IRE1alpha-mediated mRNA decay lowers plasma lipids in mice. Cell Metab. 2012, 16, 487-499. [CrossRef]

39. Upton, J.P.; Wang, L.; Han, D.; Wang, E.S.; Huskey, N.E.; Lim, L.; Truitt, M.; McManus, M.T.; Ruggero, D.; Goga, A.; et al. IRE1alpha cleaves select microRNAs during ER stress to derepress translation of proapoptotic Caspase-2. Science 2012, 338, 818-822. [CrossRef]

40. Pluquet, O.; Dejeans, N.; Bouchecareilh, M.; Lhomond, S.; Pineau, R.; Higa, A.; Delugin, M.; Combe, C.; Loriot, S.; Cubel, G.; et al. Posttranscriptional regulation of PER1 underlies the oncogenic function of IREalpha. Cancer Res. 2013, 73, 4732-4743. [CrossRef]

41. Dejeans, N.; Pluquet, O.; Lhomond, S.; Grise, F.; Bouchecareilh, M.; Juin, A.; Meynard-Cadars, M.; Bidaud-Meynard, A.; Gentil, C.; Moreau, V.; et al. Autocrine control of glioma cells adhesion and migration through IRE1alpha-mediated cleavage of SPARC mRNA. J. Cell Sci. 2012, 125, 4278-4287. [CrossRef] [PubMed]

42. Bright, M.D.; Itzhak, D.N.; Wardell, C.P.; Morgan, G.J.; Davies, F.E. Cleavage of BLOC1S1 mRNA by IRE1 Is Sequence Specific, Temporally Separate from XBP1 Splicing, and Dispensable for Cell Viability under Acute Endoplasmic Reticulum Stress. Mol. Cell Biol. 2015, 35, 2186-2202. [CrossRef] [PubMed]

43. Lu, M.; Lawrence, D.A.; Marsters, S.; Acosta-Alvear, D.; Kimmig, P.; Mendez, A.S.; Paton, A.W.; Paton, J.C.; Walter, P.; Ashkenazi, A. Opposing unfolded-protein-response signals converge on death receptor 5 to control apoptosis. Science 2014, 345, 98-101. [CrossRef]

44. Maurel, M.; Chevet, E.; Tavernier, J.; Gerlo, S. Getting RIDD of RNA: IRE1 in cell fate regulation. Trends Biochem. Sci. 2014, 39, 245-254. [CrossRef] [PubMed]

45. Korennykh, A.; Walter, P. Structural basis of the unfolded protein response. Annu. Rev. Cell Dev. Biol. 2012, 28, 251-277. [CrossRef] [PubMed]

46. Korennykh, A.V.; Egea, P.F.; Korostelev, A.A.; Finer-Moore, J.; Zhang, C.; Shokat, K.M.; Stroud, R.M.; Walter, P. The unfolded protein response signals through high-order assembly of Ire1. Nature 2009, 457, 687-693. [CrossRef]

47. Tam, A.B.; Koong, A.C.; Niwa, M. Ire1 has distinct catalytic mechanisms for XBP1/HAC1 splicing and RIDD. Cell Rep. 2014, 9, 850-858. [CrossRef]

48. Ghosh, R.; Wang, L.; Wang, E.S.; Perera, B.G.; Igbaria, A.; Morita, S.; Prado, K.; Thamsen, M.; Caswell, D.; Macias, H.; et al. Allosteric inhibition of the IRE1alpha RNase preserves cell viability and function during endoplasmic reticulum stress. Cell 2014, 158, 534-548. [CrossRef] 
49. Obacz, J.; Avril, T.; Le Reste, P.J.; Urra, H.; Quillien, V.; Hetz, C.; Chevet, E. Endoplasmic reticulum proteostasis in glioblastoma-From molecular mechanisms to therapeutic perspectives. Sci. Signal. 2017, 10. [CrossRef]

50. Auf, G.; Jabouille, A.; Guerit, S.; Pineau, R.; Delugin, M.; Bouchecareilh, M.; Magnin, N.; Favereaux, A.; Maitre, M.; Gaiser, T.; et al. Inositol-requiring enzyme 1alpha is a key regulator of angiogenesis and invasion in malignant glioma. Proc. Natl. Acad. Sci. USA 2010, 107, 15553-15558. [CrossRef]

51. Hong, S.Y.; Hagen, T. Multiple myeloma Leu167lle (c.499C>A) mutation prevents XBP1 mRNA splicing. Br. J. Haematol. 2013, 161, 898-901. [CrossRef] [PubMed]

52. Chen, X.; Iliopoulos, D.; Zhang, Q.; Tang, Q.; Greenblatt, M.B.; Hatziapostolou, M.; Lim, E.; Tam, W.L.; Ni, M.; Chen, Y.; et al. XBP1 promotes triple-negative breast cancer by controlling the HIF1alpha pathway. Nature 2014, 508, 103-107. [CrossRef] [PubMed]

53. Bagratuni, T.; Wu, P.; Gonzalez de Castro, D.; Davenport, E.L.; Dickens, N.J.; Walker, B.A.; Boyd, K.; Johnson, D.C.; Gregory, W.; Morgan, G.J.; et al. XBP1s levels are implicated in the biology and outcome of myeloma mediating different clinical outcomes to thalidomide-based treatments. Blood 2010, 116, $250-253$. [CrossRef] [PubMed]

54. Gambella, M.; Rocci, A.; Passera, R.; Gay, F.; Omede, P.; Crippa, C.; Corradini, P.; Romano, A.; Rossi, D.; Ladetto, M.; et al. High XBP1 expression is a marker of better outcome in multiple myeloma patients treated with bortezomib. Haematologica 2014, 99, e14-e16. [CrossRef]

55. Chapman, M.A.; Lawrence, M.S.; Keats, J.J.; Cibulskis, K.; Sougnez, C.; Schinzel, A.C.; Harview, C.L.; Brunet, J.P.; Ahmann, G.J.; Adli, M.; et al. Initial genome sequencing and analysis of multiple myeloma. Nature 2011, 471, 467-472. [CrossRef]

56. Leung-Hagesteijn, C.; Erdmann, N.; Cheung, G.; Keats, J.J.; Stewart, A.K.; Reece, D.E.; Chung, K.C.; Tiedemann, R.E. Xbp1s-Negative Tumor B Cells and Pre-Plasmablasts Mediate Therapeutic Proteasome Inhibitor Resistance in Multiple Myeloma. Cancer Cell 2015, 28, 541-542. [CrossRef]

57. Bertolotti, A.; Zhang, Y.; Hendershot, L.M.; Harding, H.P.; Ron, D. Dynamic interaction of BiP and ER stress transducers in the unfolded-protein response. Nat. Cell Biol. 2000, 2, 326-332. [CrossRef]

58. Harding, H.P.; Novoa, I.; Zhang, Y.; Zeng, H.; Wek, R.; Schapira, M.; Ron, D. Regulated translation initiation controls stress-induced gene expression in mammalian cells. Mol. Cell 2000, 6, 1099-1108. [CrossRef]

59. Marciniak, S.J.; Garcia-Bonilla, L.; Hu, J.; Harding, H.P.; Ron, D. Activation-dependent substrate recruitment by the eukaryotic translation initiation factor 2 kinase PERK. J. Cell Biol. 2006, 172, 201-209. [CrossRef]

60. Bobrovnikova-Marjon, E.; Grigoriadou, C.; Pytel, D.; Zhang, F.; Ye, J.; Koumenis, C.; Cavener, D.; Diehl, J.A. PERK promotes cancer cell proliferation and tumor growth by limiting oxidative DNA damage. Oncogene 2010, 29, 3881-3895. [CrossRef]

61. Zhang, W.; Hietakangas, V.; Wee, S.; Lim, S.C.; Gunaratne, J.; Cohen, S.M. ER stress potentiates insulin resistance through PERK-mediated FOXO phosphorylation. Genes Dev. 2013, 27, 441-449. [CrossRef]

62. Bobrovnikova-Marjon, E.; Pytel, D.; Riese, M.J.; Vaites, L.P.; Singh, N.; Koretzky, G.A.; Witze, E.S.; Diehl, J.A. PERK utilizes intrinsic lipid kinase activity to generate phosphatidic acid, mediate Akt activation, and promote adipocyte differentiation. Mol. Cell Biol. 2012, 32, 2268-2278. [CrossRef]

63. Nanduri, S.; Rahman, F.; Williams, B.R.; Qin, J. A dynamically tuned double-stranded RNA binding mechanism for the activation of antiviral kinase PKR. EMBO J. 2000, 19, 5567-5574. [CrossRef]

64. Ung, T.L.; Cao, C.; Lu, J.; Ozato, K.; Dever, T.E. Heterologous dimerization domains functionally substitute for the double-stranded RNA binding domains of the kinase PKR. EMBO J. 2001, 20, 3728-3737. [CrossRef]

65. Zhang, F.; Romano, P.R.; Nagamura-Inoue, T.; Tian, B.; Dever, T.E.; Mathews, M.B.; Ozato, K.; Hinnebusch, A.G. Binding of double-stranded RNA to protein kinase PKR is required for dimerization and promotes critical autophosphorylation events in the activation loop. J. Biol. Chem. 2001, 276, 24946-24958. [CrossRef]

66. Dong, J.; Qiu, H.; Garcia-Barrio, M.; Anderson, J.; Hinnebusch, A.G. Uncharged tRNA activates GCN2 by displacing the protein kinase moiety from a bipartite tRNA-binding domain. Mol. Cell 2000, 6, 269-279. [CrossRef]

67. Deng, J.; Harding, H.P.; Raught, B.; Gingras, A.C.; Berlanga, J.J.; Scheuner, D.; Kaufman, R.J.; Ron, D.; Sonenberg, N. Activation of GCN2 in UV-irradiated cells inhibits translation. Curr. Biol. 2002, 12, 1279-1286. [CrossRef]

68. Hao, S.; Sharp, J.W.; Ross-Inta, C.M.; McDaniel, B.J.; Anthony, T.G.; Wek, R.C.; Cavener, D.R.; McGrath, B.C.; Rudell, J.B.; Koehnle, T.J.; et al. Uncharged tRNA and sensing of amino acid deficiency in mammalian piriform cortex. Science 2005, 307, 1776-1778. [CrossRef] 
69. Chen, J.J.; Crosby, J.S.; London, I.M. Regulation of heme-regulated eIF-2 alpha kinase and its expression in erythroid cells. Biochimie 1994, 76, 761-769. [CrossRef]

70. Dey, S.; Tameire, F.; Koumenis, C. PERK-ing up autophagy during MYC-induced tumorigenesis. Autophagy 2013, 9, 612-614. [CrossRef]

71. Hart, L.S.; Cunningham, J.T.; Datta, T.; Dey, S.; Tameire, F.; Lehman, S.L.; Qiu, B.; Zhang, H.; Cerniglia, G.; $\mathrm{Bi}, \mathrm{M}$.; et al. ER stress-mediated autophagy promotes Myc-dependent transformation and tumor growth. J. Clin. Investig. 2012, 122, 4621-4634. [CrossRef]

72. Salaroglio, I.C.; Panada, E.; Moiso, E.; Buondonno, I.; Provero, P.; Rubinstein, M.; Kopecka, J.; Riganti, C. PERK induces resistance to cell death elicited by endoplasmic reticulum stress and chemotherapy. Mol. Cancer 2017, 16, 91. [CrossRef]

73. Zhu, H.; Chen, X.; Chen, B.; Chen, B.; Song, W.; Sun, D.; Zhao, Y. Activating transcription factor 4 promotes esophageal squamous cell carcinoma invasion and metastasis in mice and is associated with poor prognosis in human patients. PloS ONE 2014, 9, e103882. [CrossRef]

74. Atkins, C.; Liu, Q.; Minthorn, E.; Zhang, S.Y.; Figueroa, D.J.; Moss, K.; Stanley, T.B.; Sanders, B.; Goetz, A.; Gaul, N.; et al. Characterization of a novel PERK kinase inhibitor with antitumor and antiangiogenic activity. Cancer Res. 2013, 73, 1993-2002. [CrossRef]

75. Spriggs, K.A.; Bushell, M.; Willis, A.E. Translational regulation of gene expression during conditions of cell stress. Mol. Cell 2010, 40, 228-237. [CrossRef]

76. Yamasaki, S.; Anderson, P. Reprogramming mRNA translation during stress. Curr. Opin. Cell Biol. 2008, 20, 222-226. [CrossRef]

77. Furuichi, Y. Discovery of m(7)G-cap in eukaryotic mRNAs. Proc. Jpn. Acad. Ser. B Phys. Biol. Sci. 2015, 91, 394-409. [CrossRef]

78. Haimov, O.; Sinvani, H.; Dikstein, R. Cap-dependent, scanning-free translation initiation mechanisms. Biochim. Et Biophys. Acta 2015, 1849, 1313-1318. [CrossRef]

79. Hinnebusch, A.G. The scanning mechanism of eukaryotic translation initiation. Annu. Rev. Biochem. 2014, 83, 779-812. [CrossRef]

80. Jackson, R.J.; Hellen, C.U.; Pestova, T.V. The mechanism of eukaryotic translation initiation and principles of its regulation. Nat. Rev. Mol. Cell Biol. 2010, 11, 113-127. [CrossRef]

81. Sonenberg, N.; Hinnebusch, A.G. Regulation of translation initiation in eukaryotes: Mechanisms and biological targets. Cell 2009, 136, 731-745. [CrossRef]

82. Cho, P.F.; Poulin, F.; Cho-Park, Y.A.; Cho-Park, I.B.; Chicoine, J.D.; Lasko, P.; Sonenberg, N. A new paradigm for translational control: Inhibition via $5^{\prime}-3^{\prime}$ mRNA tethering by Bicoid and the eIF4E cognate 4EHP. Cell 2005, 121, 411-423. [CrossRef]

83. Chen, H.H.; Tarn, W.Y. uORF-mediated translational control: Recently elucidated mechanisms and implications in cancer. RNA Biol. 2019, 16, 1327-1338. [CrossRef]

84. Lin, Y.; May, G.E.; Kready, H.; Nazzaro, L.; Mao, M.; Spealman, P.; Creeger, Y.; McManus, C.J. Impacts of uORF codon identity and position on translation regulation. Nucleic Acids Res. 2019, 47, 9358-9367. [CrossRef]

85. Young, S.K.; Wek, R.C. Upstream Open Reading Frames Differentially Regulate Gene-specific Translation in the Integrated Stress Response. J. Biol. Chem. 2016, 291, 16927-16935. [CrossRef]

86. Baird, T.D.; Palam, L.R.; Fusakio, M.E.; Willy, J.A.; Davis, C.M.; McClintick, J.N.; Anthony, T.G.; Wek, R.C. Selective mRNA translation during eIF2 phosphorylation induces expression of IBTKalpha. Mol. Biol. Cell 2014, 25, 1686-1697. [CrossRef]

87. Hussain, T.; Llacer, J.L.; Fernandez, I.S.; Munoz, A.; Martin-Marcos, P.; Savva, C.G.; Lorsch, J.R.; Hinnebusch, A.G.; Ramakrishnan, V. Structural changes enable start codon recognition by the eukaryotic translation initiation complex. Cell 2014, 159, 597-607. [CrossRef]

88. Young, S.K.; Willy, J.A.; Wu, C.; Sachs, M.S.; Wek, R.C. Ribosome Reinitiation Directs Gene-specific Translation and Regulates the Integrated Stress Response. J. Biol. Chem. 2015, 290, 28257-28271. [CrossRef]

89. Palam, L.R.; Baird, T.D.; Wek, R.C. Phosphorylation of eIF2 facilitates ribosomal bypass of an inhibitory upstream ORF to enhance CHOP translation. J. Biol. Chem. 2011, 286, 10939-10949. [CrossRef]

90. Young, S.K.; Palam, L.R.; Wu, C.; Sachs, M.S.; Wek, R.C. Ribosome Elongation Stall Directs Gene-specific Translation in the Integrated Stress Response. J. Biol. Chem. 2016, 291, 6546-6558. [CrossRef]

91. Kurosaki, T.; Popp, M.W.; Maquat, L.E. Quality and quantity control of gene expression by nonsense-mediated mRNA decay. Nat. Rev. Mol. Cell Biol. 2019, 20, 406-420. [CrossRef] 
92. Starck, S.R.; Tsai, J.C.; Chen, K.; Shodiya, M.; Wang, L.; Yahiro, K.; Martins-Green, M.; Shastri, N.; Walter, P. Translation from the $5^{\prime}$ untranslated region shapes the integrated stress response. Science 2016, 351, aad3867. [CrossRef]

93. Schulz, J.; Mah, N.; Neuenschwander, M.; Kischka, T.; Ratei, R.; Schlag, P.M.; Castanos-Velez, E.; Fichtner, I.; Tunn, P.U.; Denkert, C.; et al. Loss-of-function uORF mutations in human malignancies. Sci. Rep. 2018, 8, 2395. [CrossRef]

94. Fawcett, T.W.; Martindale, J.L.; Guyton, K.Z.; Hai, T.; Holbrook, N.J. Complexes containing activating transcription factor (ATF)/cAMP-responsive-element-binding protein (CREB) interact with the CCAAT/enhancer-binding protein (C/EBP)-ATF composite site to regulate Gadd153 expression during the stress response. Biochem. J. 1999, 339, 135-141.

95. Harding, H.P.; Zhang, Y.; Bertolotti, A.; Zeng, H.; Ron, D. Perk is essential for translational regulation and cell survival during the unfolded protein response. Mol. Cell 2000, 5, 897-904. [CrossRef]

96. Ma, Y.; Hendershot, L.M. Delineation of a negative feedback regulatory loop that controls protein translation during endoplasmic reticulum stress. J. Biol. Chem. 2003, 278, 34864-34873. [CrossRef]

97. Marciniak, S.J.; Yun, C.Y.; Oyadomari, S.; Novoa, I.; Zhang, Y.; Jungreis, R.; Nagata, K.; Harding, H.P.; Ron, D. $\mathrm{CHOP}$ induces death by promoting protein synthesis and oxidation in the stressed endoplasmic reticulum. Genes Dev. 2004, 18, 3066-3077. [CrossRef]

98. Han, J.; Back, S.H.; Hur, J.; Lin, Y.H.; Gildersleeve, R.; Shan, J.; Yuan, C.L.; Krokowski, D.; Wang, S.; Hatzoglou, M.; et al. ER-stress-induced transcriptional regulation increases protein synthesis leading to cell death. Nat. Cell Biol. 2013, 15, 481-490. [CrossRef]

99. Lu, P.D.; Harding, H.P.; Ron, D. Translation reinitiation at alternative open reading frames regulates gene expression in an integrated stress response. J. Cell Biol. 2004, 167, 27-33. [CrossRef]

100. Vattem, K.M.; Wek, R.C. Reinitiation involving upstream ORFs regulates ATF4 mRNA translation in mammalian cells. Proc. Natl. Acad. Sci. USA 2004, 101, 11269-11274. [CrossRef]

101. Lee, Y.Y.; Cevallos, R.C.; Jan, E. An upstream open reading frame regulates translation of GADD34 during cellular stresses that induce eIF2alpha phosphorylation. J. Biol. Chem. 2009, 284, 6661-6673. [CrossRef]

102. Chiribau, C.B.; Gaccioli, F.; Huang, C.C.; Yuan, C.L.; Hatzoglou, M. Molecular symbiosis of CHOP and C/EBP beta isoform LIP contributes to endoplasmic reticulum stress-induced apoptosis. Mol. Cell Biol. 2010, 30, 3722-3731. [CrossRef]

103. Wethmar, K.; Begay, V.; Smink, J.J.; Zaragoza, K.; Wiesenthal, V.; Dorken, B.; Calkhoven, C.F.; Leutz, A. C/EBPbetaDeltauORF mice-a genetic model for uORF-mediated translational control in mammals. Genes Dev. 2010, 24, 15-20. [CrossRef]

104. Young, S.K.; Baird, T.D.; Wek, R.C. Translation Regulation of the Glutamyl-prolyl-tRNA Synthetase Gene EPRS through Bypass of Upstream Open Reading Frames with Noncanonical Initiation Codons. J. Biol. Chem. 2016, 291, 10824-10835. [CrossRef]

105. Huang, C.C.; Li, Y.; Lopez, A.B.; Chiang, C.M.; Kaufman, R.J.; Snider, M.D.; Hatzoglou, M. Temporal regulation of Cat-1 (cationic amino acid transporter-1) gene transcription during endoplasmic reticulum stress. Biochem. J. 2010, 429, 215-224. [CrossRef]

106. Yaman, I.; Fernandez, J.; Liu, H.; Caprara, M.; Komar, A.A.; Koromilas, A.E.; Zhou, L.; Snider, M.D.; Scheuner, D.; Kaufman, R.J.; et al. The zipper model of translational control: A small upstream ORF is the switch that controls structural remodeling of an mRNA leader. Cell 2003, 113, 519-531. [CrossRef]

107. Sarnow, P. Translation of glucose-regulated protein 78/immunoglobulin heavy-chain binding protein mRNA is increased in poliovirus-infected cells at a time when cap-dependent translation of cellular mRNAs is inhibited. Proc. Natl. Acad. Sci. USA 1989, 86, 5795-5799. [CrossRef]

108. Pelletier, J.; Kaplan, G.; Racaniello, V.R.; Sonenberg, N. Cap-independent translation of poliovirus mRNA is conferred by sequence elements within the $5^{\prime}$ noncoding region. Mol. Cell Biol. 1988, 8, 1103-1112. [CrossRef]

109. Jang, S.K.; Krausslich, H.G.; Nicklin, M.J.; Duke, G.M.; Palmenberg, A.C.; Wimmer, E. A segment of the 5' nontranslated region of encephalomyocarditis virus RNA directs internal entry of ribosomes during in vitro translation. J. Virol. 1988, 62, 2636-2643. [CrossRef]

110. Trono, D.; Andino, R.; Baltimore, D. An RNA sequence of hundreds of nucleotides at the $5^{\prime}$ end of poliovirus RNA is involved in allowing viral protein synthesis. J. Virol. 1988, 62, 2291-2299. [CrossRef]

111. Pelletier, J.; Sonenberg, N. Internal initiation of translation of eukaryotic mRNA directed by a sequence derived from poliovirus RNA. Nature 1988, 334, 320-325. [CrossRef] 
112. Macejak, D.G.; Sarnow, P. Internal initiation of translation mediated by the $5^{\prime}$ leader of a cellular mRNA. Nature 1991, 353, 90-94. [CrossRef]

113. Johannes, G.; Sarnow, P. Cap-independent polysomal association of natural mRNAs encoding c-myc, BiP, and eIF4G conferred by internal ribosome entry sites. RNA-A Publ. RNA Soc. 1998, 4, 1500-1513. [CrossRef]

114. Mokrejs, M.; Masek, T.; Vopalensky, V.; Hlubucek, P.; Delbos, P.; Pospisek, M. IRESite-A tool for the examination of viral and cellular internal ribosome entry sites. Nucleic Acids Res. 2010, 38, D131-D136. [CrossRef]

115. Weingarten-Gabbay, S.; Elias-Kirma, S.; Nir, R.; Gritsenko, A.A.; Stern-Ginossar, N.; Yakhini, Z.; Weinberger, A.; Segal, E. Comparative genetics. Systematic discovery of cap-independent translation sequences in human and viral genomes. Science 2016, 351. [CrossRef]

116. Holcik, M.; Sonenberg, N. Translational control in stress and apoptosis. Nat. Rev. Mol. Cell Biol. 2005, 6, 318-327. [CrossRef]

117. Stoneley, M.; Chappell, S.A.; Jopling, C.L.; Dickens, M.; MacFarlane, M.; Willis, A.E. c-Myc protein synthesis is initiated from the internal ribosome entry segment during apoptosis. Mol. Cell. Biol. 2000, 20, 1162-1169. [CrossRef]

118. Nevins, T.A.; Harder, Z.M.; Korneluk, R.G.; Holcik, M. Distinct regulation of internal ribosome entry site-mediated translation following cellular stress is mediated by apoptotic fragments of eIF4G translation initiation factor family members eIF4GI and p97/DAP5/NAT1. J. Biol. Chem. 2003, 278, 3572-3579. [CrossRef]

119. Lewis, S.M.; Cerquozzi, S.; Graber, T.E.; Ungureanu, N.H.; Andrews, M.; Holcik, M. The eIF4G homolog DAP5/p97 supports the translation of select mRNAs during endoplasmic reticulum stress. Nucleic Acids Res. 2008, 36, 168-178. [CrossRef]

120. Spriggs, K.A.; Cobbold, L.C.; Jopling, C.L.; Cooper, R.E.; Wilson, L.A.; Stoneley, M.; Coldwell, M.J.; Poncet, D.; Shen, Y.C.; Morley, S.J.; et al. Canonical initiation factor requirements of the Myc family of internal ribosome entry segments. Mol. Cell Biol. 2009, 29, 1565-1574. [CrossRef]

121. Thoma, C.; Bergamini, G.; Galy, B.; Hundsdoerfer, P.; Hentze, M.W. Enhancement of IRES-mediated translation of the c-myc and BiP mRNAs by the poly(A) tail is independent of intact eIF4G and PABP. Mol. Cell 2004, 15, 925-935. [CrossRef]

122. Gerlitz, G.; Jagus, R.; Elroy-Stein, O. Phosphorylation of initiation factor-2 alpha is required for activation of internal translation initiation during cell differentiation. Eur. J. Biochem. 2002, 269, 2810-2819. [CrossRef]

123. Jaud, M.; Philippe, C.; Van Den Berghe, L.; Segura, C.; Mazzolini, L.; Pyronnet, S.; Laurell, H.; Touriol, C. The PERK Branch of the Unfolded Protein Response Promotes DLL4 Expression by Activating an Alternative Translation Mechanism. Cancers 2019, 11, 142. [CrossRef]

124. Philippe, C.; Dubrac, A.; Quelen, C.; Desquesnes, A.; Van Den Berghe, L.; Segura, C.; Filleron, T.; Pyronnet, S.; Prats, H.; Brousset, P.; et al. PERK mediates the IRES-dependent translational activation of mRNAs encoding angiogenic growth factors after ischemic stress. Sci. Signal. 2016, 9, ra44. [CrossRef]

125. Subkhankulova, T.; Mitchell, S.A.; Willis, A.E. Internal ribosome entry segment-mediated initiation of c-Myc protein synthesis following genotoxic stress. Biochem. J. 2001, 359, 183-192. [CrossRef]

126. Thakor, N.; Holcik, M. IRES-mediated translation of cellular messenger RNA operates in eIF2alphaindependent manner during stress. Nucleic Acids Res. 2012, 40, 541-552. [CrossRef]

127. Tinton, S.A.; Schepens, B.; Bruynooghe, Y.; Beyaert, R.; Cornelis, S. Regulation of the cell-cycle-dependent internal ribosome entry site of the PITSLRE protein kinase: Roles of Unr (upstream of N-ras) protein and phosphorylated translation initiation factor eIF-2alpha. Biochem. J. 2005, 385, 155-163. [CrossRef]

128. Lewis, S.M.; Holcik, M. For IRES trans-acting factors, it is all about location. Oncogene 2008, 27, $1033-1035$. [CrossRef]

129. Kim, Y.K.; Back, S.H.; Rho, J.; Lee, S.H.; Jang, S.K. La autoantigen enhances translation of BiP mRNA. Nucleic Acids Res. 2001, 29, 5009-5016. [CrossRef]

130. Holcik, M.; Gordon, B.W.; Korneluk, R.G. The internal ribosome entry site-mediated translation of antiapoptotic protein XIAP is modulated by the heterogeneous nuclear ribonucleoproteins $\mathrm{C} 1$ and $\mathrm{C} 2$. Mol. Cell Biol. 2003, 23, 280-288. [CrossRef]

131. Damiano, F.; Rochira, A.; Tocci, R.; Alemanno, S.; Gnoni, A.; Siculella, L. hnRNP A1 mediates the activation of the IRES-dependent SREBP-1a mRNA translation in response to endoplasmic reticulum stress. Biochem. J. 2013, 449, 543-553. [CrossRef] [PubMed] 
132. Chappell, S.A.; LeQuesne, J.P.; Paulin, F.E.; deSchoolmeester, M.L.; Stoneley, M.; Soutar, R.L.; Ralston, S.H.; Helfrich, M.H.; Willis, A.E. A mutation in the c-myc-IRES leads to enhanced internal ribosome entry in multiple myeloma: A novel mechanism of oncogene de-regulation. Oncogene 2000, 19, 4437-4440. [CrossRef] [PubMed]

133. Walters, B.; Thompson, S.R. Cap-Independent Translational Control of Carcinogenesis. Front. Oncol. 2016, 6, 128. [CrossRef] [PubMed]

134. Muranen, T.; Selfors, L.M.; Worster, D.T.; Iwanicki, M.P.; Song, L.; Morales, F.C.; Gao, S.; Mills, G.B.; Brugge, J.S. Inhibition of PI3K/mTOR leads to adaptive resistance in matrix-attached cancer cells. Cancer Cell 2012, 21, 227-239. [CrossRef]

135. Silvera, D.; Arju, R.; Darvishian, F.; Levine, P.H.; Zolfaghari, L.; Goldberg, J.; Hochman, T.; Formenti, S.C.; Schneider, R.J. Essential role for eIF4GI overexpression in the pathogenesis of inflammatory breast cancer. Nat. Cell Biol. 2009, 11, 903-908. [CrossRef]

136. Halaby, M.J.; Harris, B.R.; Miskimins, W.K.; Cleary, M.P.; Yang, D.Q. Deregulation of Internal Ribosome Entry Site-Mediated p53 Translation in Cancer Cells with Defective p53 Response to DNA Damage. Mol. Cell Biol. 2015, 35, 4006-4017. [CrossRef]

137. Sharathchandra, A.; Katoch, A.; Das, S. IRES mediated translational regulation of p53 isoforms. Wiley Interdiscip. Rev. RNA 2014, 5, 131-139. [CrossRef]

138. Halaby, M.J.; Li, Y.; Harris, B.R.; Jiang, S.; Miskimins, W.K.; Cleary, M.P.; Yang, D.Q. Translational Control Protein 80 Stimulates IRES-Mediated Translation of p53 mRNA in Response to DNA Damage. Biomed. Res. Int. 2015, 2015, 708158. [CrossRef]

139. Takagi, M.; Absalon, M.J.; McLure, K.G.; Kastan, M.B. Regulation of p53 translation and induction after DNA damage by ribosomal protein L26 and nucleolin. Cell 2005, 123, 49-63. [CrossRef]

140. Weingarten-Gabbay, S.; Khan, D.; Liberman, N.; Yoffe, Y.; Bialik, S.; Das, S.; Oren, M.; Kimchi, A. The translation initiation factor DAP5 promotes IRES-driven translation of p53 mRNA. Oncogene 2014, 33, 611-618. [CrossRef]

141. Halaby, M.J.; Yang, D.Q. p53 translational control: A new facet of p53 regulation and its implication for tumorigenesis and cancer therapeutics. Gene 2007, 395, 1-7. [CrossRef] [PubMed]

142. Arcondeguy, T.; Lacazette, E.; Millevoi, S.; Prats, H.; Touriol, C. VEGF-A mRNA processing, stability and translation: A paradigm for intricate regulation of gene expression at the post-transcriptional level. Nucleic Acids Res. 2013, 41, 7997-8010. [CrossRef] [PubMed]

143. Arnaud, E.; Touriol, C.; Boutonnet, C.; Gensac, M.C.; Vagner, S.; Prats, H.; Prats, A.C. A new 34-kilodalton isoform of human fibroblast growth factor 2 is cap dependently synthesized by using a non-AUG start codon and behaves as a survival factor. Mol. Cell Biol. 1999, 19, 505-514. [CrossRef] [PubMed]

144. Bastide, A.; Karaa, Z.; Bornes, S.; Hieblot, C.; Lacazette, E.; Prats, H.; Touriol, C. An upstream open reading frame within an IRES controls expression of a specific VEGF-A isoform. Nucleic Acids Res. 2008, 36, 2434-2445. [CrossRef]

145. Bonnet-Magnaval, F.; Philippe, C.; Van Den Berghe, L.; Prats, H.; Touriol, C.; Lacazette, E. Hypoxia and ER stress promote Staufen1 expression through an alternative translation mechanism. Biochem. Biophys. Res. Commun. 2016, 479, 365-371. [CrossRef]

146. Bornes, S.; Boulard, M.; Hieblot, C.; Zanibellato, C.; Iacovoni, J.S.; Prats, H.; Touriol, C. Control of the vascular endothelial growth factor internal ribosome entry site (IRES) activity and translation initiation by alternatively spliced coding sequences. J. Biol. Chem. 2004, 279, 18717-18726. [CrossRef]

147. Li, W.; Thakor, N.; Xu, E.Y.; Huang, Y.; Chen, C.; Yu, R.; Holcik, M.; Kong, A.N. An internal ribosomal entry site mediates redox-sensitive translation of Nrf2. Nucleic Acids Res. 2010, 38, 778-788. [CrossRef]

148. Morfoisse, F.; Kuchnio, A.; Frainay, C.; Gomez-Brouchet, A.; Delisle, M.B.; Marzi, S.; Helfer, A.C.; Hantelys, F.; Pujol, F.; Guillermet-Guibert, J.; et al. Hypoxia induces VEGF-C expression in metastatic tumor cells via a HIF-1alpha-independent translation-mediated mechanism. Cell Rep. 2014, 6, 155-167. [CrossRef]

149. Rubtsova, M.P.; Sizova, D.V.; Dmitriev, S.E.; Ivanov, D.S.; Prassolov, V.S.; Shatsky, I.N. Distinctive properties of the 5'-untranslated region of human hsp70 mRNA. J. Biol. Chem. 2003, 278, 22350-22356. [CrossRef]

150. Yang, Q.; Sarnow, P. Location of the internal ribosome entry site in the $5^{\prime}$ non-coding region of the immunoglobulin heavy-chain binding protein (BiP) mRNA: Evidence for specific RNA-protein interactions. Nucleic Acids Res. 1997, 25, 2800-2807. [CrossRef]

151. Karaa, Z.S.; Iacovoni, J.S.; Bastide, A.; Lacazette, E.; Touriol, C.; Prats, H. The VEGF IRESes are differentially susceptible to translation inhibition by miR-16. RNA 2009, 15, 249-254. [CrossRef] [PubMed] 
152. Chan, C.P.; Kok, K.H.; Tang, H.M.; Wong, C.M.; Jin, D.Y. Internal ribosome entry site-mediated translational regulation of ATF4 splice variant in mammalian unfolded protein response. Biochim. Et Biophys. Acta 2013, 1833, 2165-2175. [CrossRef] [PubMed]

153. Bourougaa, K.; Naski, N.; Boularan, C.; Mlynarczyk, C.; Candeias, M.M.; Marullo, S.; Fahraeus, R. Endoplasmic reticulum stress induces G2 cell-cycle arrest via mRNA translation of the p53 isoform p53/47. Mol. Cell 2010, 38, 78-88. [CrossRef] [PubMed]

154. Ray, P.S.; Grover, R.; Das, S. Two internal ribosome entry sites mediate the translation of p53 isoforms. EMBO Rep. 2006, 7, 404-410. [CrossRef] [PubMed]

155. Andreev, D.E.; O'Connor, P.B.; Loughran, G.; Dmitriev, S.E.; Baranov, P.V.; Shatsky, I.N. Insights into the mechanisms of eukaryotic translation gained with ribosome profiling. Nucleic Acids Res. 2017, 45, 513-526. [CrossRef] [PubMed]

156. Jopling, C.L.; Spriggs, K.A.; Mitchell, S.A.; Stoneley, M.; Willis, A.E. L-Myc protein synthesis is initiated by internal ribosome entry. RNA 2004, 10, 287-298. [CrossRef]

157. Le Quesne, J.P.; Stoneley, M.; Fraser, G.A.; Willis, A.E. Derivation of a structural model for the c-myc IRES. J. Mol. Biol. 2001, 310, 111-126. [CrossRef]

158. Mitchell, S.A.; Spriggs, K.A.; Coldwell, M.J.; Jackson, R.J.; Willis, A.E. The Apaf-1 internal ribosome entry segment attains the correct structural conformation for function via interactions with PTB and unr. Mol. Cell 2003, 11, 757-771. [CrossRef]

159. King, H.A.; Cobbold, L.C.; Willis, A.E. The role of IRES trans-acting factors in regulating translation initiation. Biochem. Soc. Trans. 2010, 38, 1581-1586. [CrossRef]

160. Henis-Korenblit, S.; Strumpf, N.L.; Goldstaub, D.; Kimchi, A. A novel form of DAP5 protein accumulates in apoptotic cells as a result of caspase cleavage and internal ribosome entry site-mediated translation. Mol. Cell Biol. 2000, 20, 496-506. [CrossRef]

161. Henis-Korenblit, S.; Shani, G.; Sines, T.; Marash, L.; Shohat, G.; Kimchi, A. The caspase-cleaved DAP5 protein supports internal ribosome entry site-mediated translation of death proteins. Proc. Natl. Acad. Sci. USA 2002, 99, 5400-5405. [CrossRef] [PubMed]

162. Marash, L.; Kimchi, A. DAP5 and IRES-mediated translation during programmed cell death. Cell Death Differ. 2005, 12, 554-562. [CrossRef] [PubMed]

163. Warnakulasuriyarachchi, D.; Cerquozzi, S.; Cheung, H.H.; Holcik, M. Translational induction of the inhibitor of apoptosis protein HIAP2 during endoplasmic reticulum stress attenuates cell death and is mediated via an inducible internal ribosome entry site element. J. Biol. Chem. 2004, 279, 17148-17157. [CrossRef] [PubMed]

164. Bevilacqua, E.; Wang, X.; Majumder, M.; Gaccioli, F.; Yuan, C.L.; Wang, C.; Zhu, X.; Jordan, L.E.; Scheuner, D.; Kaufman, R.J.; et al. eIF2alpha phosphorylation tips the balance to apoptosis during osmotic stress. J. Biol. Chem. 2010, 285, 17098-17111. [CrossRef]

165. Shi, Y.; Yang, Y.; Hoang, B.; Bardeleben, C.; Holmes, B.; Gera, J.; Lichtenstein, A. Therapeutic potential of targeting IRES-dependent c-myc translation in multiple myeloma cells during ER stress. Oncogene 2016, 35, 1015-1024. [CrossRef]

166. Dobbyn, H.C.; Hill, K.; Hamilton, T.L.; Spriggs, K.A.; Pickering, B.M.; Coldwell, M.J.; de Moor, C.H.; Bushell, M.; Willis, A.E. Regulation of BAG-1 IRES-mediated translation following chemotoxic stress. Oncogene 2008, 27, 1167-1174. [CrossRef]

167. Morfoisse, F.; Tatin, F.; Hantelys, F.; Adoue, A.; Helfer, A.C.; Cassant-Sourdy, S.; Pujol, F.; Gomez-Brouchet, A.; Ligat, L.; Lopez, F.; et al. Nucleolin Promotes Heat Shock-Associated Translation of VEGF-D to Promote Tumor Lymphangiogenesis. Cancer Res. 2016, 76, 4394-4405. [CrossRef]

168. Bornes, S.; Prado-Lourenco, L.; Bastide, A.; Zanibellato, C.; Iacovoni, J.S.; Lacazette, E.; Prats, A.C.; Touriol, C.; Prats, H. Translational induction of VEGF internal ribosome entry site elements during the early response to ischemic stress. Circ. Res. 2007, 100, 305-308. [CrossRef]

169. Creancier, L.; Morello, D.; Mercier, P.; Prats, A.C. Fibroblast growth factor 2 internal ribosome entry site (IRES) activity ex vivo and in transgenic mice reveals a stringent tissue-specific regulation. J. Cell Biol. 2000, 150, 275-281. [CrossRef]

170. Laklai, H.; Laval, S.; Dumartin, L.; Rochaix, P.; Hagedorn, M.; Bikfalvi, A.; Le Guellec, S.; Delisle, M.B.; Schally, A.V.; Susini, C.; et al. Thrombospondin-1 is a critical effector of oncosuppressive activity of sst2 somatostatin receptor on pancreatic cancer. Proc. Natl. Acad. Sci. USA 2009, 106, 17769-17774. [CrossRef] 
171. Lang, K.J.; Kappel, A.; Goodall, G.J. Hypoxia-inducible factor-1alpha mRNA contains an internal ribosome entry site that allows efficient translation during normoxia and hypoxia. Mol. Biol. Cell 2002, 13, 1792-1801. [CrossRef] [PubMed]

172. Carmeliet, P.; Ferreira, V.; Breier, G.; Pollefeyt, S.; Kieckens, L.; Gertsenstein, M.; Fahrig, M.; Vandenhoeck, A.; Harpal, K.; Eberhardt, C.; et al. Abnormal blood vessel development and lethality in embryos lacking a single VEGF allele. Nature 1996, 380, 435-439. [CrossRef] [PubMed]

173. Ferrara, N.; Carver-Moore, K.; Chen, H.; Dowd, M.; Lu, L.; O’Shea, K.S.; Powell-Braxton, L.; Hillan, K.J.; Moore, M.W. Heterozygous embryonic lethality induced by targeted inactivation of the VEGF gene. Nature 1996, 380, 439-442. [CrossRef] [PubMed]

174. Gale, N.W.; Dominguez, M.G.; Noguera, I.; Pan, L.; Hughes, V.; Valenzuela, D.M.; Murphy, A.J.; Adams, N.C.; Lin, H.C.; Holash, J.; et al. Haploinsufficiency of delta-like 4 ligand results in embryonic lethality due to major defects in arterial and vascular development. Proc. Natl. Acad. Sci. USA 2004, 101, 15949-15954. [CrossRef]

175. Blais, J.D.; Addison, C.L.; Edge, R.; Falls, T.; Zhao, H.; Wary, K.; Koumenis, C.; Harding, H.P.; Ron, D.; Holcik, M.; et al. Perk-dependent translational regulation promotes tumor cell adaptation and angiogenesis in response to hypoxic stress. Mol. Cell Biol. 2006, 26, 9517-9532. [CrossRef]

176. Hur, K.Y.; So, J.S.; Ruda, V.; Frank-Kamenetsky, M.; Fitzgerald, K.; Koteliansky, V.; Iwawaki, T.; Glimcher, L.H.; Lee, A.H. IRE1alpha activation protects mice against acetaminophen-induced hepatotoxicity. J. Exp. Med. 2012, 209, 307-318. [CrossRef]

177. Oikawa, D.; Tokuda, M.; Hosoda, A.; Iwawaki, T. Identification of a consensus element recognized and cleaved by IRE1 alpha. Nucleic Acids Res. 2010, 38, 6265-6273. [CrossRef]

178. Gaddam, D.; Stevens, N.; Hollien, J. Comparison of mRNA localization and regulation during endoplasmic reticulum stress in Drosophila cells. Mol. Biol. Cell 2013, 24, 14-20. [CrossRef]

179. Jagannathan, S.; Reid, D.W.; Cox, A.H.; Nicchitta, C.V. De novo translation initiation on membrane-bound ribosomes as a mechanism for localization of cytosolic protein mRNAs to the endoplasmic reticulum. RNA 2014, 20, 1489-1498. [CrossRef]

180. Reid, D.W.; Chen, Q.; Tay, A.S.; Shenolikar, S.; Nicchitta, C.V. The unfolded protein response triggers selective mRNA release from the endoplasmic reticulum. Cell 2014, 158, 1362-1374. [CrossRef]

181. Reid, D.W.; Nicchitta, C.V. Primary role for endoplasmic reticulum-bound ribosomes in cellular translation identified by ribosome profiling. J. Biol. Chem. 2012, 287, 5518-5527. [CrossRef] [PubMed]

182. Moore, K.; Hollien, J. Ire1-mediated decay in mammalian cells relies on mRNA sequence, structure, and translational status. Mol. Biol. Cell 2015, 26, 2873-2884. [CrossRef] [PubMed]

183. Iwawaki, T.; Hosoda, A.; Okuda, T.; Kamigori, Y.; Nomura-Furuwatari, C.; Kimata, Y.; Tsuru, A.; Kohno, K. Translational control by the ER transmembrane kinase/ribonuclease IRE1 under ER stress. Nat. Cell Biol. 2001, 3, 158-164. [CrossRef] [PubMed]

184. Imagawa, Y.; Hosoda, A.; Sasaka, S.; Tsuru, A.; Kohno, K. RNase domains determine the functional difference between IRE1alpha and IRE1beta. FEBS Lett. 2008, 582, 656-660. [CrossRef] [PubMed]

185. Khajuria, R.K.; Munschauer, M.; Ulirsch, J.C.; Fiorini, C.; Ludwig, L.S.; McFarland, S.K.; Abdulhay, N.J.; Specht, H.; Keshishian, H.; Mani, D.R.; et al. Ribosome Levels Selectively Regulate Translation and Lineage Commitment in Human Hematopoiesis. Cell 2018, 173, 90-103 e119. [CrossRef] [PubMed]

186. Acosta-Alvear, D.; Karagoz, G.E.; Frohlich, F.; Li, H.; Walther, T.C.; Walter, P. The unfolded protein response and endoplasmic reticulum protein targeting machineries converge on the stress sensor IRE1. eLife 2018, 7. [CrossRef]

187. Leppek, K.; Das, R.; Barna, M. Functional 5' UTR mRNA structures in eukaryotic translation regulation and how to find them. Nat. Rev. Mol. Cell Biol. 2018, 19, 158-174. [CrossRef]

188. Lee, A.S.; Kranzusch, P.J.; Cate, J.H. eIF3 targets cell-proliferation messenger RNAs for translational activation or repression. Nature 2015, 522, 111-114. [CrossRef]

189. Lee, A.S.; Kranzusch, P.J.; Doudna, J.A.; Cate, J.H. eIF3d is an mRNA cap-binding protein that is required for specialized translation initiation. Nature 2016, 536, 96-99. [CrossRef]

190. Fraser, C.S.; Doudna, J.A. Structural and mechanistic insights into hepatitis C viral translation initiation. Nat. Rev. Microbiol. 2007, 5, 29-38. [CrossRef] 
191. Bhardwaj, U.; Powell, P.; Goss, D.J. Eukaryotic initiation factor (eIF) 3 mediates Barley Yellow Dwarf Viral mRNA $3^{\prime}-5^{\prime}$ UTR interactions and 40 S ribosomal subunit binding to facilitate cap-independent translation. Nucleic Acids Res. 2019, 47, 6225-6235. [CrossRef] [PubMed]

192. Cattie, D.J.; Richardson, C.E.; Reddy, K.C.; Ness-Cohn, E.M.; Droste, R.; Thompson, M.K.; Gilbert, W.V.; Kim, D.H. Mutations in Nonessential eIF3k and eIF31 Genes Confer Lifespan Extension and Enhanced Resistance to ER Stress in Caenorhabditis elegans. PLoS Genet. 2016, 12, e1006326. [CrossRef] [PubMed]

193. Guan, B.J.; van Hoef, V.; Jobava, R.; Elroy-Stein, O.; Valasek, L.S.; Cargnello, M.; Gao, X.H.; Krokowski, D.; Merrick, W.C.; Kimball, S.R.; et al. A Unique ISR Program Determines Cellular Responses to Chronic Stress. Mol. Cell 2017, 68, 885-900 e886. [CrossRef] [PubMed]

194. Meyer, K.D.; Patil, D.P.; Zhou, J.; Zinoviev, A.; Skabkin, M.A.; Elemento, O.; Pestova, T.V.; Qian, S.B.; Jaffrey, S.R. 5' UTR m(6)A Promotes Cap-Independent Translation. Cell 2015, 163, 999-1010. [CrossRef]

195. Desrosiers, R.; Friderici, K.; Rottman, F. Identification of methylated nucleosides in messenger RNA from Novikoff hepatoma cells. Proc. Natl. Acad. Sci. USA 1974, 71, 3971-3975. [CrossRef]

196. Rottman, F.; Shatkin, A.J.; Perry, R.P. Sequences containing methylated nucleotides at the $5^{\prime}$ termini of messenger RNAs: Possible implications for processing. Cell 1974, 3, 197-199. [CrossRef]

197. Meyer, K.D.; Saletore, Y.; Zumbo, P.; Elemento, O.; Mason, C.E.; Jaffrey, S.R. Comprehensive analysis of mRNA methylation reveals enrichment in 3' UTRs and near stop codons. Cell 2012, 149, 1635-1646. [CrossRef]

198. Zhou, J.; Wan, J.; Gao, X.; Zhang, X.; Jaffrey, S.R.; Qian, S.B. Dynamic m(6)A mRNA methylation directs translational control of heat shock response. Nature 2015, 526, 591-594. [CrossRef]

199. Shi, H.; Wei, J.; He, C. Where, When, and How: Context-Dependent Functions of RNA Methylation Writers, Readers, and Erasers. Mol. Cell 2019, 74, 640-650. [CrossRef]

200. Hsu, P.J.; Zhu, Y.; Ma, H.; Guo, Y.; Shi, X.; Liu, Y.; Qi, M.; Lu, Z.; Shi, H.; Wang, J.; et al. Ythdc2 is an $\mathrm{N}(6)$-methyladenosine binding protein that regulates mammalian spermatogenesis. Cell Res. 2017, 27, 1115-1127. [CrossRef]

201. Shi, H.; Wang, X.; Lu, Z.; Zhao, B.S.; Ma, H.; Hsu, P.J.; Liu, C.; He, C. YTHDF3 facilitates translation and decay of N(6)-methyladenosine-modified RNA. Cell Res. 2017, 27, 315-328. [CrossRef] [PubMed]

202. Wang, X.; Zhao, B.S.; Roundtree, I.A.; Lu, Z.; Han, D.; Ma, H.; Weng, X.; Chen, K.; Shi, H.; He, C. N(6)-methyladenosine Modulates Messenger RNA Translation Efficiency. Cell 2015, 161, 1388-1399. [CrossRef] [PubMed]

203. Choe, J.; Lin, S.; Zhang, W.; Liu, Q.; Wang, L.; Ramirez-Moya, J.; Du, P.; Kim, W.; Tang, S.; Sliz, P.; et al. mRNA circularization by METTL3-eIF3h enhances translation and promotes oncogenesis. Nature 2018, 561, 556-560. [CrossRef] [PubMed]

204. Lin, S.; Choe, J.; Du, P.; Triboulet, R.; Gregory, R.I. The m(6)A Methyltransferase METTL3 Promotes Translation in Human Cancer Cells. Mol. Cell 2016, 62, 335-345. [CrossRef]

205. Barbieri, I.; Tzelepis, K.; Pandolfini, L.; Shi, J.; Millan-Zambrano, G.; Robson, S.C.; Aspris, D.; Migliori, V.; Bannister, A.J.; Han, N.; et al. Promoter-bound METTL3 maintains myeloid leukaemia by m(6)A-dependent translation control. Nature 2017, 552, 126-131. [CrossRef]

206. Zhou, J.; Wan, J.; Shu, X.E.; Mao, Y.; Liu, X.M.; Yuan, X.; Zhang, X.; Hess, M.E.; Bruning, J.C.; Qian, S.B. N(6)-Methyladenosine Guides mRNA Alternative Translation during Integrated Stress Response. Mol. Cell 2018, 69, 636-647 e637. [CrossRef]

(C) 2020 by the authors. Licensee MDPI, Basel, Switzerland. This article is an open access article distributed under the terms and conditions of the Creative Commons Attribution (CC BY) license (http://creativecommons.org/licenses/by/4.0/). 